\title{
The Leaf Structure of the Iridaceae, considered in Relation to the Phyllode Theory.
}

\author{
BY \\ AGNES ARBER, D.SC., F.L.S., \\ Keddey' Fletcher.Warr Student of the University of London.
}

With sixty-six Figures in the Text.

\section{Contents.}

1. INTRODUCTION . . . . 3OF

2. Ensiform Petiolar leaves a 302

(i) The occurrence of ensiform leaves in the Jridaceae - • 302

(ii) Views bitherto held on the nature. of the ensiform leaf 303

(iii) The ensiform leaf as a petiolar structure, and the comparison with Acacia phyllodes

(iv) Semi-equitant leaves . 303 306

(v) The association of ensiform leaf and winged axis in certain Monocotyledons and Acacias .

3. NON;ENSIFORM LEAVES IN CERTAIN

IRIDOIDEAE .

(i) 'Radial' leaves in Iris and other Iridoideae, and their relation to Acacia phyllodes - 310

(ii) Transitional and bifacial leaftypes in Tris and Moraca

301
302
302
303
303
306
308
Phyllodes of ACACIA $\quad \therefore \quad$ - 317

5. Fibrosis in Irids and Acacias . 319

6. Foliated Leaves in the IrinOIDEae aND IXIOIDEae . · 320

7. The Leaves of the Crocoideae. 323

8. ASYMMETRy IN CERTAIN IRID Leaves. - • • • $\cdot 328$

9. The Evolutionary History of THE IRID LeAF $\quad \cdot \quad \cdot \quad \cdot \quad \cdot 329$

(i) The primitive character of the ensiform leaf-type . . $\quad 329$

$310 \quad$ (ii) The progression from the ensiform leaf-type $\quad \cdot \quad \cdot \quad$. 331

10. Summary

Alphabetical List of Memoirs CITED • • . . . $\cdot 335$

\section{INTRODUCTION.}

THE present paper forms one of a series ${ }^{1}$ in which I am attempting to test the validity of the phyllode theory by studying the results of its application to the leaves of various groups of Monocotyledons. In this instalment I propose to deal with the Iridaceae-that family in which, or my view, the phyllodic leaf finds perhaps its most varied and complete

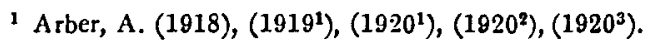

[Annals of Botany, Vol. XXXV. No. CXXXIX. July, 192x.] 
expression. The thesis which I hope here to substantiate is that the leaf of the Iridaceae has no trae lamina, but represents, in every case, either. a petiole and leaf-base, or a leaf-base alone.

A considerable body of work on the leaf anatomy of the Irids already exists, ${ }^{1}$ that of the Italian writer, Hermann Ross, being particularly thorough and detailed. But I have found that, since none of the botanists who have hitherto dealt with the subject have even considered the possibility of the leaf in question being merely a modified leaf-base and petiole, their observations seldom include answers to the particular questions to which the phyllode theory gives rise. I have, therefore, found it necessary to attempt an independent examination of the principal leaf-types met with in the Iridaceae. In this connexion I must express my gratitude, for their kindness in supplying me with material, to the Director and to the Keeper of the Herbarium, the Royal Botanic Gardens, Kew, and to the Keeper of the Department of Botany, British Museum (Nat. Hist.), and also to Professor Sir Isaac Bayley Balfour, F.R.S., Professor Béguinot, of Padua, Mr. Joseph Benbow, of La Mortola, the late M: Augustin de Candolle, of Geneva, Mr. F. J. Chittenden, Miss Mabel Cobbe, Mr. W. R. Dykes, Mr. C. C. Lacaita, Miss C. E. Larter, Mrs. J. J. Lister, Mr. R. I. Lynch, Mr. J. H. Maiden, F.R.S., of Sidney, Dr. Schonland, of Grahamstown, and Professor A. C. Seward, F.R.S. I am much indebted to Mr. W. R. Dykes and to Professor J. Bretland Fàrmer, F.R.S., for suggestions and criticism, and to Miss E. R. Saunders for facilities for carrying out this work in the Balfour Laboratory, Cambridge.

Regarding the classification of the Iridaceae there is considerable difference of opinion; in the present paper I have provisionally adopted the scheme used in Engler's 'Pflanzenfamilien'.2.

\section{ENSIFORM Petiolar LFaves.}

(i) The occurrence of ensiform leaves in the Iridaceac.

In a previous paper ${ }^{3}$. I have briefly discussed the ensiform (or isobilateral equitant) leaf, and its relation to other phyllodic types. This form of leaf-the most widespread of those met with amongst Monocotyledons which show the type of anatomy that $I$ have interpreted as phyllodic-is characteristic of the majority of the Iridaceae ${ }^{4}$ it occurs in a large proportion of the Iridoideae and Ixioideae, though not in the Crocoideae. In examining the leaves of the family in the herbarium of the British Museum (Nat. Hist.) I have seen ensiform leaves in the following genera : Acidanthera, Antholyza, Aristea, Belancanda, Bobartia, Crocosmia,

I Chodat, R., and Balicka-Iwanowska, G. (1892); Balicka-Iwanowska, G. (1892-3); Ross, H. (1899-3); Lindman, C. A. M. (1899).
$2 \mathrm{Pax}, \mathrm{F} .(1888)$.
Arber, A. (1918), p. $4^{82 .}$
1 Ross, H. (1892-3). 
Cypella, Dierama, Diplarrhena, Freesia, Geissorhiza, Gladiolus, Hesperantha, Iris, Ixia, Lapeyrousia, Libertia, Marica, Melasphaerula, Micranthus, Moraea (Dietcs), Patersonia, Schizostylis, Sisyrinchinn, Sparaxis, Synnotia, Tapeinia, Tritonia, Watsonia, Witsenia. The prevalence of the ensiform leaf, indicated by the length of this list (which is not exhaustive), seems to justify us in opening our consideration of the Iridaceae with a renewed attempt to understand this foliar type, which has been the subject of much controversy.

(ii) Viewes hitherto held on the nature of the ensiform leaf.

The anomalous character of the equitant Iris leaf has long been recognized; in Lyte's 'Herball' of 1578 it is compared to 'the blade of a two-edged swoorde'. It is one of the most familiar examples of the 'monofacial' leaf as opposed to the more usual flattened dorsiventral type. According to Celakovský, ${ }^{1}$ Velenovsky, ${ }^{2}$ and others, ${ }^{3}$ the ensiform leaf arises through congenital concrescence. This view has been most thoroughly and consistently elaborated by Celakovský, who follows out and accepts all the deductions that arise logically out of his theory. $\mathrm{He}$ holds that the bifacial leaf is universally primary, and that all monofacial leaves are produced by concrescence of the halves, to right and left of the midrib, which were originally free and flat. $\mathrm{He}$ even goes so far as to suppose that all petioles came originally into existence through congenital folding and fusion of the narrowed basal region of bifacial, blades. Velenovský, however, while accepting Čelakovský's view for the ensiform leaf, and even for those species of Iris which have a 'radial' limb, refuses to apply it to such apparently similar.monofacial leaves as those of Funcus communis, which he interprets as due to the thickening of an originally flat blade. Goebel, ${ }^{4}$ on the other hand, takes a view entirely opposed to those of Čelakovský and Velenovský. He declines altogether to accept the idea of congenital concrescence, but he gives no explicit statement of his opinion as to the morphological nature of the limb. He treats it as a new winglike outgrowth from the original leaf primordium, and, as far as one can judge from the way in which he discusses it, he seems to regard it as an organ sui generis.

(iii) The ensiform leaf as a petiolar structure, and the comparison with Acacia phyllodes.

In my 1918 paper ${ }^{5} I$ have put forward the view that the equitant leaf which characterizes the Irises belonging to the Sections Apogon, Pogoniris,

1 Celakovský, L. J. (1903).

2 Velenovský, J. (1907).

3 Gray, Asa (1887); Chodat, R., and Balicka-Iwanowska, G. (1892); Balicka-Iwanowska, G. $(1592-3)$; \&c.

- Goebel, K. (1905) and (1913).

Arber, A. (1918); Candolle, A. P. de (1827), recognized the leaf of Iris as petiolar. 
Cypella, Dierama, Diplarrhena, Freesia, Geissorhiza, Gladiolus, Hesperantha, Iris, Ixia, Lapeyrousia, Libertia, Marica, Melasphaerula, Micranthus, Moraea (Dietcs), Patersonia, Schizostylis, Sisyrinchinn, Sparaxis, Synnotia, Tapeinia, Tritonia, Watsonia, Witsenia. The prevalence of the ensiform leaf, indicated by the length of this list (which is not exhaustive), seems to justify us in opening our consideration of the Iridaceae with a renewed attempt to understand this foliar type, which has been the subject of much controversy.

(ii) Viewes hitherto held on the nature of the ensiform leaf.

The anomalous character of the equitant Iris leaf has long been recognized; in Lyte's 'Herball' of 1578 it is compared to 'the blade of a two-edged swoorde'. It is one of the most familiar examples of the 'monofacial' leaf as opposed to the more usual flattened dorsiventral type. According to Celakovský, ${ }^{1}$ Velenovsky, ${ }^{2}$ and others, ${ }^{3}$ the ensiform leaf arises through congenital concrescence. This view has been most thoroughly and consistently elaborated by Celakovský, who follows out and accepts all the deductions that arise logically out of his theory. $\mathrm{He}$ holds that the bifacial leaf is universally primary, and that all monofacial leaves are produced by concrescence of the halves, to right and left of the midrib, which were originally free and flat. $\mathrm{He}$ even goes so far as to suppose that all petioles came originally into existence through congenital folding and fusion of the narrowed basal region of bifacial, blades. Velenovský, however, while accepting Čelakovský's view for the ensiform leaf, and even for those species of Iris which have a 'radial' limb, refuses to apply it to such apparently similar.monofacial leaves as those of Funcus communis, which he interprets as due to the thickening of an originally flat blade. Goebel, ${ }^{4}$ on the other hand, takes a view entirely opposed to those of Čelakovský and Velenovský. He declines altogether to accept the idea of congenital concrescence, but he gives no explicit statement of his opinion as to the morphological nature of the limb. He treats it as a new winglike outgrowth from the original leaf primordium, and, as far as one can judge from the way in which he discusses it, he seems to regard it as an organ sui generis.

(iii) The ensiform leaf as a petiolar structure, and the comparison with Acacia phyllodes.

In my 1918 paper ${ }^{5} I$ have put forward the view that the equitant leaf which characterizes the Irises belonging to the Sections Apogon, Pogoniris,

1 Celakovský, L. J. (1903).

2 Velenovský, J. (1907).

3 Gray, Asa (1887); Chodat, R., and Balicka-Iwanowska, G. (1892); Balicka-Iwanowska, G. $(1592-3)$; \&c.

- Goebel, K. (1905) and (1913).

Arber, A. (1918); Candolle, A. P. de (1827), recognized the leaf of Iris as petiolar. 


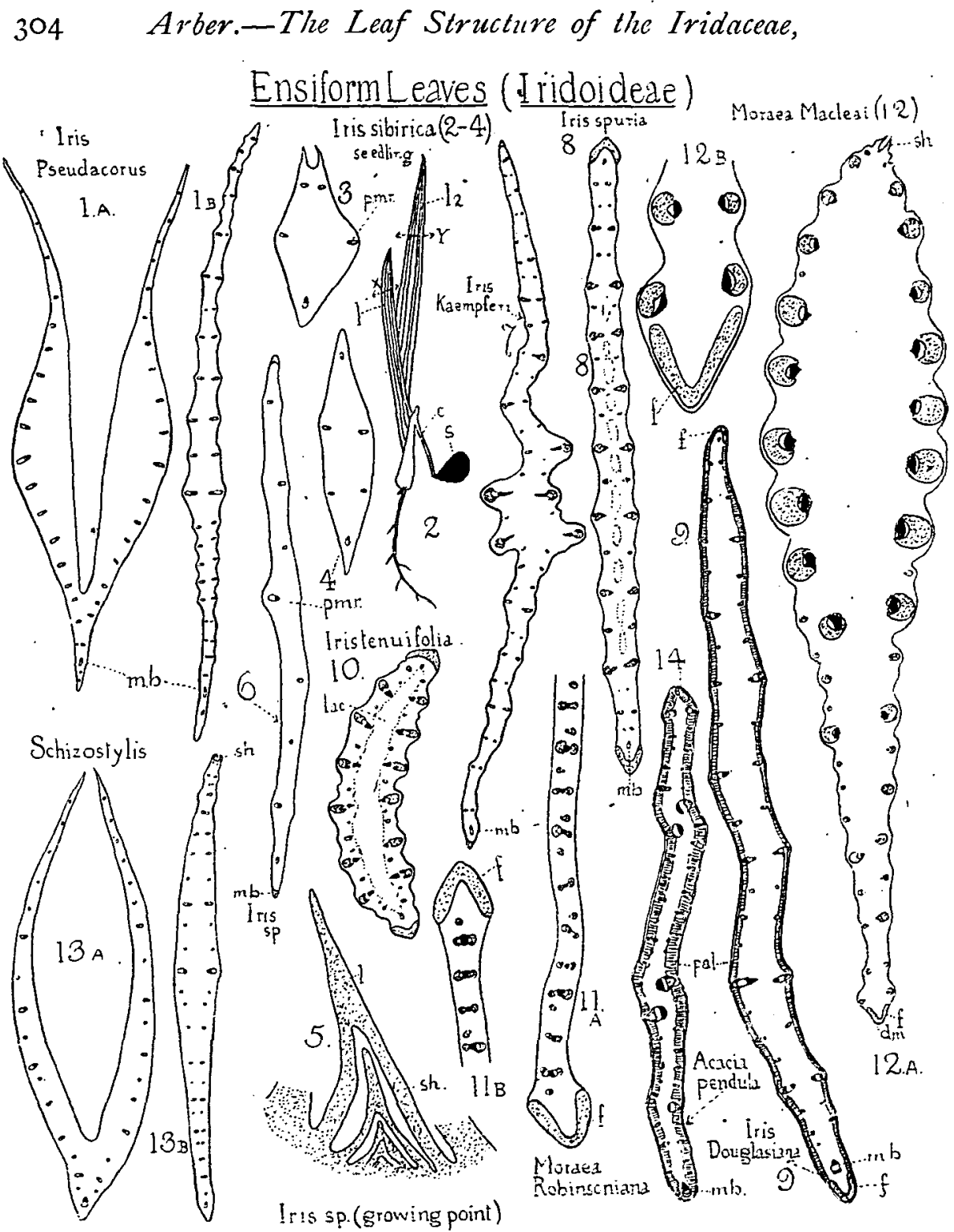

FIGs. 1-14. (All figures in this paper, nnless otherwise stated, are drawings of transverse sections of limbs of leaves, with the adaxial side towards the top of the page; xylem, solid black ; phloem, white; fibres, dotted; m.b., median bundle.) Fig. 1 , Iris Pseudacorus, L. ( $\times 7$ ), only principal bundles indicated; Fig. I A, sheath; Fig. I B, limb. Figs. 2-4, Iris sibirica, L.; Fig. 2, seedling (nat. size); s., seed; $c_{\text {., }}$ cotyledon; $l_{1}$ and $l_{2}$, first and second plumular leaves. Fig. 3, transverse section of $l_{1}$ at $x\left(x_{23}\right)$. Fig. 4, transverse section second leaf of another seedling at about level $\mathrm{y}$ in $l_{2}\left(\times{ }_{23} 3\right)$. Fig. 5 , Iris sp., longitudinal section stem apex with young leaves ; l., solid $\operatorname{limb} ;$ sh., sheath $\left(x_{4}\right)$. Fig. 6, Iris sp., China $\left(x_{14}\right)$. Fig. 7 , Iris Kaempferi, Sieb. $(\times 7)$. Fig. 8, Iris sputia, L. $\left(x_{14}\right)$. Fig. 9, Iris Douglasiana, Herb. ( $x$ 1 4$)$, the palisade parenchyma, pal., more developed on left-hand face. Fig. Io, Iris tenuifolia, Pall. ( $\times$ I4); lac., lacuna crossed by trabeculae. Fig. II, Moraea Robinsoniana, C. Moore et F. Muell. ( $x$ 14). To

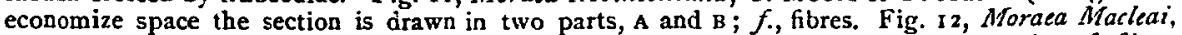
Hort.; Fig. $12 \mathrm{~A}$, limb at extreme top of junction with sheath, sh.; d.m., dorsal margin ; $f$, fibres $\left(x 1_{4}\right)$; Fig. $12 \mathrm{~B}$, dorsal margin of Fig. i2 A $\left(x_{4 i}\right)$. Fig. I3, Schizostylis coccinea, Backh. et Harv. ( $\times 7)$; Fig. 13 A, sheath; Fig. 13 B, limb. Fig. 14, Acacia pendula, A. Cunn. ( $\times$ I 4$)$. 
\&c., did not arise by congenital concrescence, but is best regarded as a petiolar phyllode, comparable with a vertical Acacia phyllode, from which it differs in possessing a sheathing base. I tried to show that this view is supported by a study of the external form and internal structure, by a comparison with other 'monofacial' types, especially those met with in the Iridaceae, and also by the facts of the ontogeny as described by Goebel and Trécul. Since that paper was written, I have examined the apical bud of an Iris with ensiform leaves, and I have found that by dissecting it under the simple microscope I could satisfy myself that the leaves, down to one which was less than $\mathrm{I} \mathrm{mm}$. in its greatest dimension, showed a solid upper region distinct from the sheathing base. Fig. 5 represents a section from a microtome series passing longitudinally through a similar apical bud, in which the same distinction of solid terminal limb $(l$. and sheathing base $(s h$.$) can be recognized even in leaves whose youth is$ extreme. The ontogeny thus yields no evidence at all for congenital concrescence. The same is true of the seedling structure (Fig. 2), for the solid phyllodic character is already recognizable even in the first plumular leaves (Figs. 3 and 4 ).

Figs. I-Io illustrate the general anatomy of various ensiform Iris leaves. In Iris Pseudacorus, L. (Figs. I A and B), and I. spuria, L. (Fig. 8), the bundles on the two sides of the leaf are equal and opposite; in I. Kaempferi, Sieb., which is conspicuously ribbed (Fig. 7), and I. Douglasiana, Herb. (Fig. 9), the bundles on either side arre found to be unequal in size and somewhat irregularly disposed, while in an undetermined species from China (Fig. 6) the bundles alternate. I also include here a sketch of I. tennifolia, Pall. (Fig. 10), because it has been figured by Chodat and Balicka-Iwanowska ${ }^{1}$ as lacking a median bundle, whereas $I$ find it to be of the normal Iris type in this respect.

The ensiform leaves of Moraea Robinsoniana, C. Moore et F. Muell., and M. Macleai, Hort. (Iridoideae), are represented in Figs. II and I2. Figs. $13 \mathrm{~A}$ and $\mathrm{B}$ show the leaf structure in the Kaffir Lily, Schizostylis coccinea, Backh. et Harv. (Ixioideae), which is essentially similar to that of Iris Pseudaconus.

In my previous paper ${ }^{2}$ the phyllodes of Acacia neriifolia, A. Cunn., A. scirpifolia, Meissn., and $A$. Cyclops, A. Cunn., were figured and compared with the leaves of various Iridaçeae; a further study of Acacias has shown that this comparison is even more widely applicable than was then

" supposed. Fig. 14 illustrates the structure of the phyllode of Acacia pendula, A. Cunn., which may be compared with the ensiform leaves of the genus Iris, especially with I. Douglasiana (Fig. 9). Figs. 40-4, p. 318, demonstrate the relation of Sparaxis, and of two ensiform species of

1 Clodat, R, and Balicka-Iwanowska, G. (1892), Fig. 1o, p. $25^{8}$.

$=$ Arber, A. (1918), Figs. 1 A and B, 2 A-D, p. 474 , and Fig. 21, p. 483 . 
Gladiolus, to Acacia neurophylla, W. V. Fitz, and A. uncinella, Benth.; Figs. 45 and 46 show the close resemblance between Gladiolus ornatus, Klatt, and Acacia incurva, Benth., while Figs. 27 and 28, p. $31 \mathrm{I}$, indicate the identity in type of Sisyrinchium junceum, E. Mey., and Acacia teretifolia, Benth. The similarity of these Irid and Acacia leaves seems to me to supply a strong argument against the congenital concrescence view. There can obviously be no question of concrescence in Acacia, since here we have no sheathing base, and thus the limb cannot possibly be interpreted as arising through the fusion of the margins of such a sheath. Yet the parallelism between the very various types met with among Acacia phyllodes, and many of the Irid leaf forms, is too exact in all essentials to be treated as fortuitous; it appears far more likely that the same morphological interpretation applies to both. The evidence of the leaf succession in the seedling makes it certain that in many Acacias the leaf of the mature plant is a petiolar phyllode, and the balance of probability favours the idea that the Irid leaf should come under the same category.

\section{(iv) Semi-equitant leaves.}

In a previous paper ${ }^{1}$ I drew attention, very briefly, to the case of the Liliaceous plant, Phormizm tcnax, Forst., the New Zealand Flax; further work has inclined me to an alternative interpretation of the curious leaf structure of this plant-an interpretation which $I$ think is more likely to prove valid than the view I tentatively suggested in 1918. In Phormizum and the related genus Dianella, there is, in the mature leaves, a sheathing base ( $a$ in Figs. 15 and 22) and a normal bifacial limb ( $c$ in Figs. I 5 and 22), but between these parts there is a short, vertically flattened region ( $b$ in Figs. 15 and 22) whose structure and anatomy (Figs. 19 and 23) recall the limb-or rather the transition region between sheath and limb-in the ensiform species of Iris. In consequence of this peculiarity, Velenovsk' ${ }^{2}$ describes the leaves of Phormizm and Dianella as 'semi-equitant', and claims them as an obvious case of congenital concrescence. To test his view I have looked into the ontogeny of the leaf, which I find to be wholly different from that of Iris. The very young leaves are entirely open and sheathing (Figs. 16 and 17 ), and this bifacial stage, in which there is no vertical ensiform region, continues until the leaves have reached a considerable size. For instance, in a leaf a little more than $30 \mathrm{~cm}$. long, the closed vertical region was found to be just beginning to differentiate itself from the sheathing base. In the seedling, also, the first plumular leaves are entirely open and sheath-like (Figs. 2I A-C). The evidence from ontogeny and from seedling structure thus appears definitely to support Velenovskýs contention that we have here a genuine instance of congenital

$$
1 \text { Arber, A. (1915). } 2 \text { Velenovsk', J. (1907). }
$$


concrescence. But the same line of evidence seems to me to indicate that the leaf of Iris is wholly different in its morphology from those of Phormium and Dianella, and that it does not, as Velenovský assumes, represent a case in which the congenital concrescence of Phorminum has been carried to an

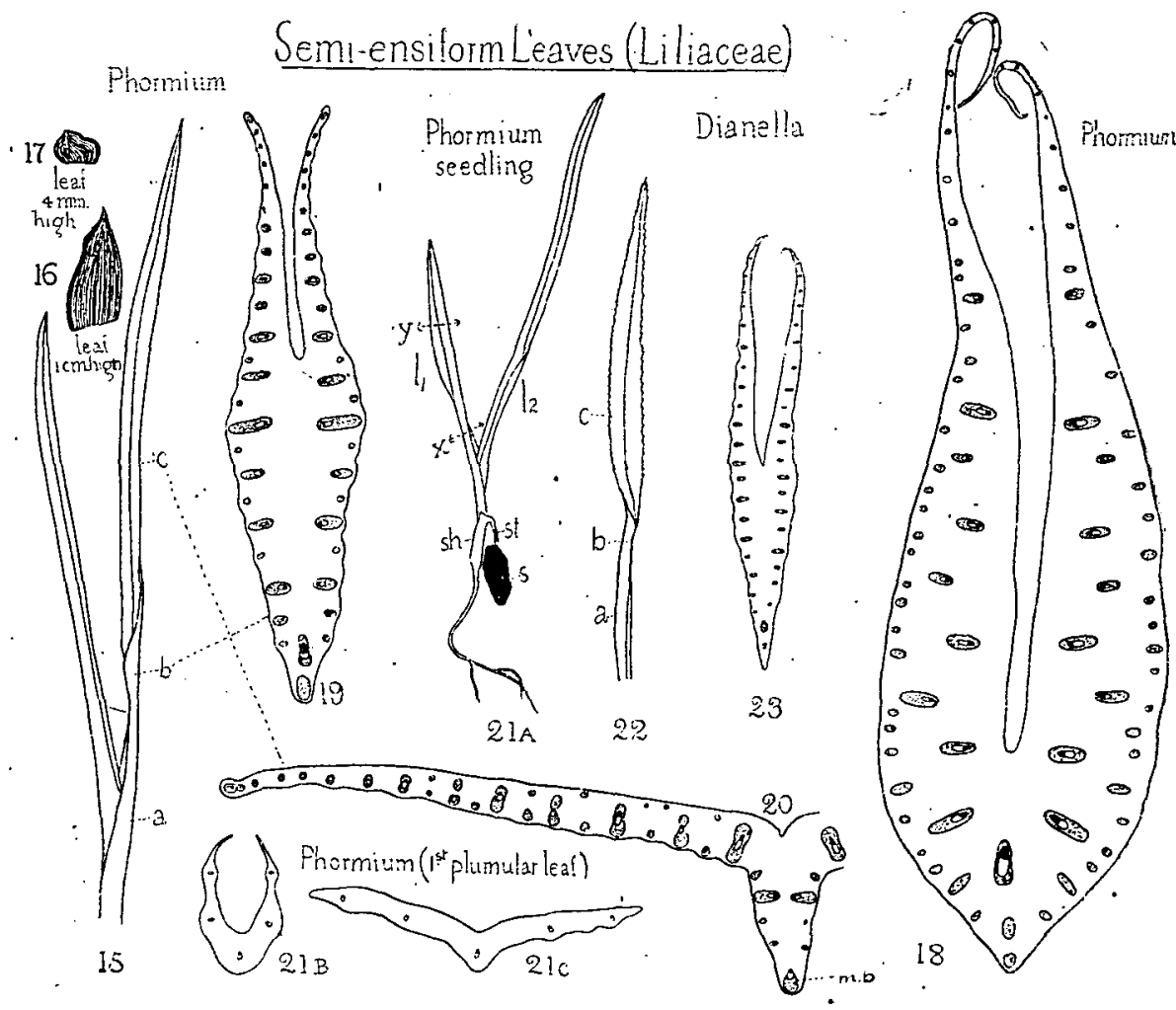

FIgs. I5-23. Figs, I5-21, Phormitum tenax, Forst. Fig. Is, two of the younger leaves of shoot $\left(\times \frac{1}{6}\right)$; the left-hand leaf is open to the base, with no concrescent region; the right-hand leaf has an open sheath at $a$, a concrescent region at $b$, and a flat limb at $c$. Fig. I6, youngest leaf of shoot in Fig. I5, open to base (slightly enlarged). Fig. 17 , leaf $4 \mathrm{~mm}$. high from another shoot, open to base (slightly reduced). Fig. I8, transverse section at $a$ across sheathing region of righthand leaf in Fig. I5 ( $\times 9$, circa). Fig. I9, transverse section at $b$ across concrescent region of righthand leaf in Fig. I5 ( $\times 9$, circa). Fig. 20, transverse section at 9 .(incomplete) across limb region of right-hand leaf in Fig. I5 ( $\times 9$, circa). Fig. 2 I A-C, seedling; Fig. 2 I A, seedling $(x-2) l_{1}$, ist leaf ; $l_{2}$, 2nd leaf; sh., sheath of cotyledon; st., stalk of cotyledon; s., seed; Fig. 2 I B, transverse section of $l_{1}$ in Fig..21 A, at level X ( $\times I_{5}$, circa); Fig. $2 \mathrm{I}$.C, transverse section of $l_{1}$ in Fig. $2 \mathrm{I} \mathrm{A}$ at level $\mathrm{Y}$ $\left(X_{15}\right.$, circa). Figs. $i_{2}$ and 23 , Dianella nemorosa, Lam. Fig. 2 2, leaf with sheathing region, $a$, concrescent region, $b$, and open limb, $c$ (reduced). Fig. 23, transverse section of leaf in Fig. 22 at level $b$, where fusion is most complete ( $\times 9$, circa).

extreme point: I look upon Phormizm and Dianella as plants in which a partially ' pseudo-phyllodic' leaf structure and anatomy have been reached as a secondary modification. These two Liliaceous genera would thus be best treated at present as a case apart. It is possible that certain other ' monofacial' leaves among the Monocotyledons may also prove, on further study, to be comparable with those of Phormium and Dianella. 
(v) The association of ensiform leaf and zuinged axis in certain Monocotyledons and Acacias.

A peculiarity which, in many cases among the Iridaceae, is associated with an equitant leaf, is the winging of the aerial axis in the plane of flattening of the leaf limb. In the herbarium of the British Museum (Nat. Hist.) I have observed this winging in the following genera and species :-

Aristea alata, Baker; A. anceps, Eckl. ; A. cladocarpa, Baker; A. compressa, Buching.

Bobartia gladiata, Ker-Gawl.

Lapeyrousia abyssinica, Baker; L. compressa, Pourr.

Marica caeruiea, Ker-Gawl.; M. gracilis, Herb.; M. Northiana, KerGawl.

Sisyrinchium acre, H. Mann; S. alatum, Hook.; S. angustifolium, Mill. (Figs. $25 \mathrm{C}$ and E); S. arizonicum, Roth; S. bogotense, H. B. et K.; S. californicum, Dryand.; S. chilense, Hook.; S.convolutum, Nocca (Fig. 25 B) ; S. distantiflorum, Kränzl ; S. grande, Baker ; S. hirsutum, Baker; S. incurvatum, Gardn. (Fig. 25 A) ; S. iridifolium, H. B. et K.: S. micranthum, Cav. ; S. palmifolium, L.; S. restioides, Spreng.; S. tinctorium, H. B. et K. (Fig. 25 D); S. vaginatum, Spreng.

When the winging is examined in detail, it is found that the leaf-base is continued downwards on either side of the true axis, from which it often remains conspicuously distinct (e.g. Sisyrinchizum incurvatum, Gardn., Fig: $25 \mathrm{~A}$ ). This winging is chiefly to be observed in inflorescence axes, since these are frequently the only aerial stems produced by the plants of this family. In such cases it is the spathe below the inflorescence which is continued downwards to form the wing (e.g. Sisyrinchium tinctorium, H. B. et K., Fig. 25 D). The sharp distinction between the cylindrical axial region $(a x$.$) and the flattened foliar region (f$.$) is very noticeable in$ the anatomy, e.g. Sisyrinchium angustifolium, Mill., Figs. $25 \mathrm{C}$ and E. The almost equal development of the wings on the two sides of the axis in this case, is due to the fact that the spathe forms a closed sheath round the inflorescence for some little distance. above its attachment, and its downward continuation is thus capable of forming a wing both on the midrib side and on the side of the fused margins. This case may be contrasted with that of Acorns Calamus, L. (Aroideae), Fig. 26 A, in which the spathe is not sheathing, but is connected at the base of the spadix by a very narrow region of attachment. As a result, its downward prolongation produces a wing, but only on the side corresponding to the midrib, m.r. (Fig. 26 B). 


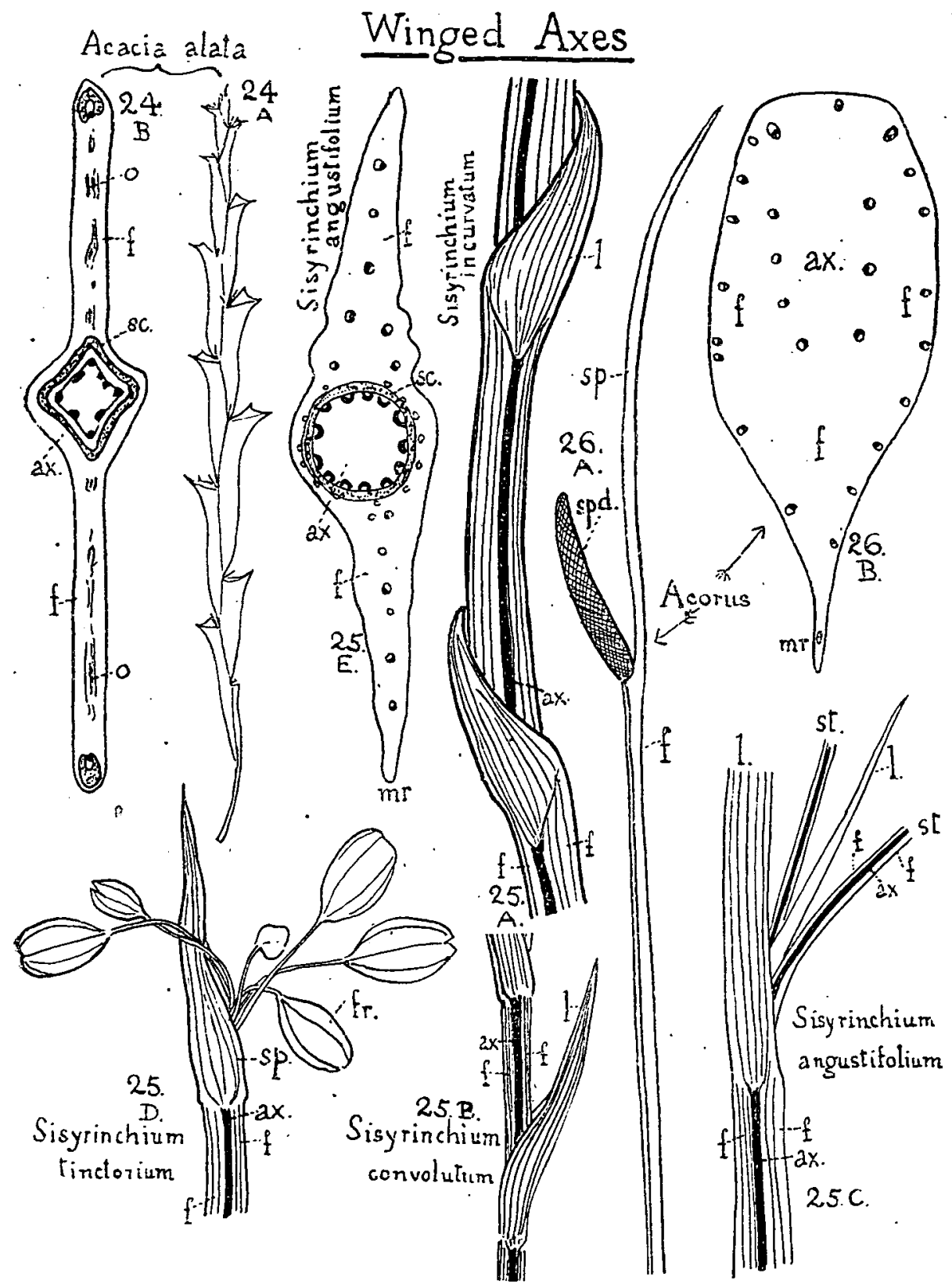

FIgS. 24-6. Figs. 24 A and B, Acacia alata, R- Br.; Fig. 24 A, shoot (nat. size) to show brses of 2 -ranked phyllodes decurrent through two internodes, producing winged axis; Fig. 24 B, transverse section winged axis $(x 28) ; a x$., axial region; $f$., foliar region; sc., 'fibrous hollow cylinder; 0. , bundles cut obliquely. Figs. 25 A-E, Sisyrinchium; throughout, $a x$. $=$ axis (which is indicated in solid black), and $f$. $=$ foliar wing of stem; Fig. 25 A, S. incurvatum, Gardn. (nat. size), axis with equitant leaves (l.) reduced almost to sheathing bases; Fig. $25 \mathrm{~B}, S$. convolutum, Nocca (nat. size); Fig. $25 \mathrm{C}, S$. angustifolizm, Mill., part of branched axis (nat. size); Fig. $25 \mathrm{D}$, $S$. tinctorium, H. B. and K., top of infructescence axis (nat. size) with spathe, sp., and fruits, $f r$. ; Fig. $25 \mathrm{E}, S$. angustifolium, Mill., transverse section winged axis $(\times 28)$; m.r., continuation of dorsal margin of leaf next above; sc, fibrous hollow cylinder. Figs. $26 \mathrm{~A}$ and $\mathrm{k}$, Acorus Calamus, L.; Fig. 26 A, fertile axis, much reduced; spd, spadix; sp., spathe; $f$., winged side of axis; Fig. 26 B, transverse section winged axis below spathe $(x \eta) ; m . r_{.}$, continuation of midrib region of spathe. The numerous small bundles lying close to the epidermis are omitted. 
The interest of the winged axis, from the standpoint of the phyllode theory, lies in the fact that, just as the main features of the isobilateral equitant leaf of the Irids may be compared with those of Acacia phyllodes, so even the minor peculiarity of the winged axis finds a parallel among the phyllodic Acacias. Acacia alata, R. Br. (Figs. 24 A and B), has two opposite rows of reduced leaves, whose downward continuation produces a winged axis bearing a general resemblance to that of Sisyrinchium, \&c., though the occurrence of the wing on the two sides is here due to the fact that each of the two alternating phyllode bases is decurrent through two internodes. Transverse sections show that the parallelism is not confined to mere externals (cf. Figs. $24 \mathrm{~B}$ and $25 \mathrm{E}$ ); in both cases there is a central axial region (ax.)-radial in structure and surrounded by a sheath of fibrous tissuc-entirely distinct from the associated lateral wings $(f$.$) .$

\section{NON-ENSIFORM LEAVES IN CERTAIN IRIDOIDEAE.}

\section{(i) 'Radial' leaves in Iris and other Iridoideae, and their relation to}

\section{Acacia phyllodes.}

Within the genus Acacia we find every transition between phyllodes which are completely flattened in the vertical plane (Figs. 14, p. 304, and $4 \mathrm{I}$ and $\left.42, \mathrm{p} \cdot 3^{\mathrm{I}} 8\right)^{1}$ and others which are cylindrical and terete (Fig. 28 ,

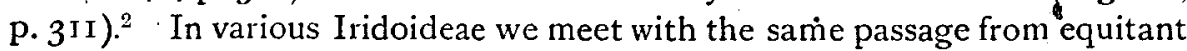
leaves to others that are more nearly radial. The leaves of most Irises of the Apogon Section are characteristically ensiform (e. g. Iris Pseudacorus, Figs. I A and B, and I. spuria, Fig. 8), but the genus also includes 'radial' leaves. Iris tuberosa, L. (Hermodactylus tuberosus, Mill.), is a plant in which the ensiform $/ r$ is leaf has been modified into a remarkable tetragonal form. Figs. $29 \mathrm{~A}-\mathrm{C}$, drawn from a microtome series, show that at the extreme base there is a closed sheath (Fig. 29 A) which opens out a little higher up (Fig. 29 B) and gradually passes into a solid limb, of diamondshaped section (Fig. $29 \mathrm{C}$ ). The median strand (m.b.) and main laterals ( $m . l$.) occupy three of the four angles, and the ventral margin $(v \cdot r$.) can be distinguished by the fact that it has no bundle with the xylem pointing directly inwards. Higher up, in the mature part of the leaf (Fig. 29 D), we find that each of the four ribs has grown out into a slight keel, supplied as a rule by two small bundles $\left(b_{._{1}}\right.$ and $\left.b_{._{2}}\right)$ which appear to arise as branches from the main bundles. Close to the apex the fibrous strands, which occupy the angles of the leaf, become increasingly conspicuous (Fig. $29 \mathrm{E}$ ).

The bulbous. Irises of the Tetragonae Section (I. reticulata, Bieb., I. Histrio, Reichb., I. Vartani, Foster, and I. Bakeriana, Foster) have

1 See also Arter, A. (1918), Fig. 2 D, p. 474, and Fig. 21, p. $48_{3}$.

2 Ibid., Fig. I B, p. 474. 
' radial' leaves, with four to eight angles or ribs, more or less resembling those of Hermodactylus. We may take the leaf of $I$. reticulata as an example. In the case of Hermodactylus the leaf is fairly symmetrical about a plane passing through the dorsal and ventral margins, but in the

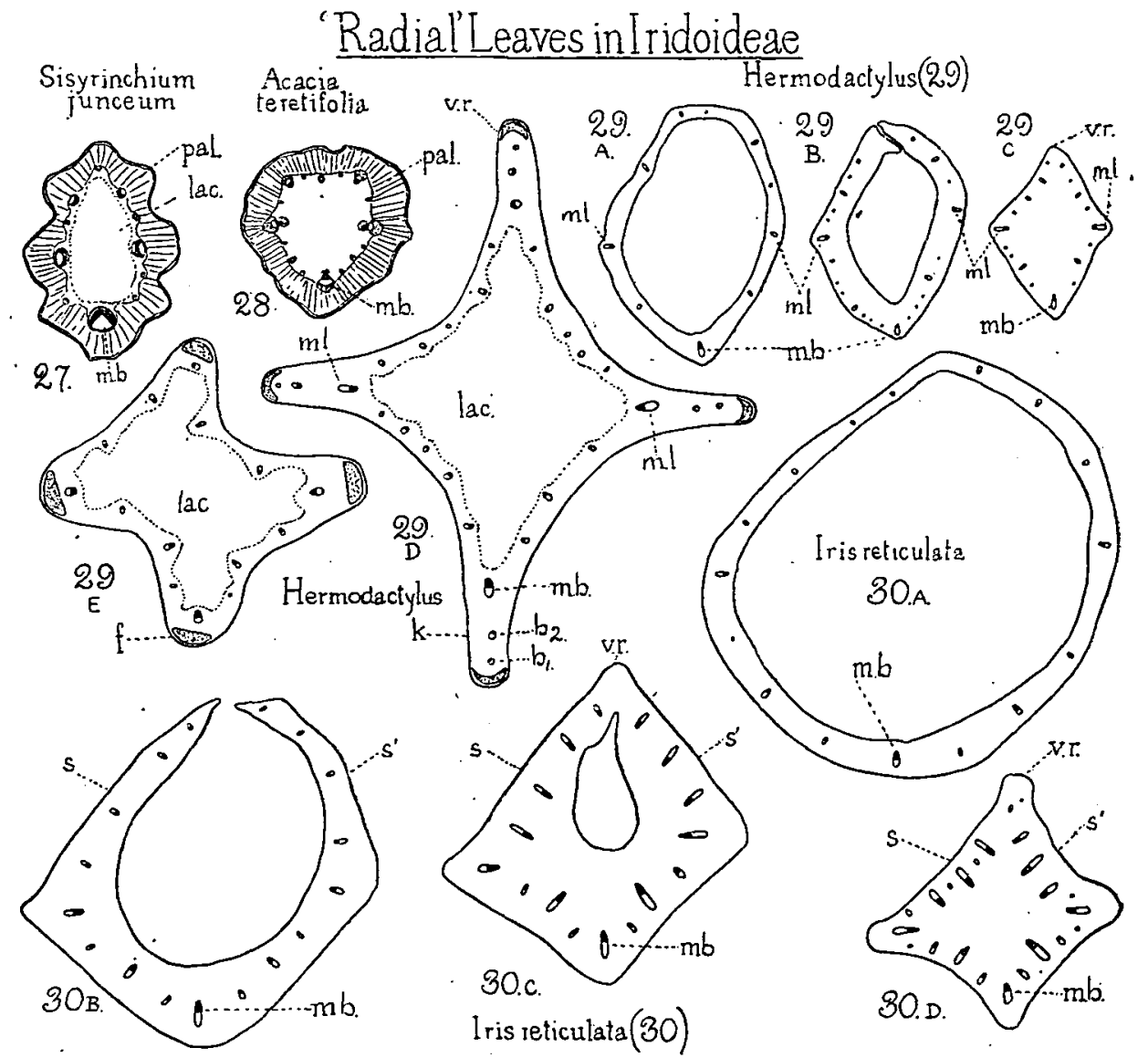

Figs. 27-30. Fig. 27, Sisyrinchium junceum, E. Mey., transverse section limb of leaf; pal., 3-tiered palisade parenchyma ( $\times 23$ ). Fig. 28, Acacia teretifolia, Benth., transverse section phyllode; pal., palisade parenchyma of about two tiers of cells $(\times 23)$. Figs. 29 A-E, Hermodactylus tuberosus, Mill.; m.l., main lateral; Figs. 29 A-C, sections from microtome series through base of leaf ( $x$ I4) showing transition from closed sheath tbrough open sheath to solid limb; v.r., ventral ridge; Fig. 29 D, mature part of another leaf; $k$., keel; $b_{.1}$ and $b_{.3}$, bundles of keel; lac., lacuna ; Fig. $29 \mathrm{E}_{i}$ section close to apex of same leaf; $f$., fibres; lac., lacuna crossed by trabeculae. Fig. 3o A-D, Iris reticulato, Bielb., sections from a series through base of limb of leaf ( $X$ I4). Fig. $30 \mathrm{~A}$ and $\mathrm{B}$, sheath; Fig. $30 \mathrm{C}$, transition region; Fig. $30 \mathrm{D}$, limb showing asymmetry of the two lateral faces, $s$ and $s^{\prime}$, which meet at the ventral ridge, v.r.

case of Iris reticulata this is not so. When the leaf is examined in situ, the flat surface $(s, \mathrm{Fig}$. $3 \circ \mathrm{D})$ has all the appearance of being an upper or ventral surface, but Figs. $30 \mathrm{~A}-\mathrm{D}$, drawn.from a series of transverse sections through a leaf-base, show that the leaf is markedly asymmetrical; the ridge, 
v.r., is ventral, while the unequal surfaces, $s$ and $s^{\prime}$, are lateral. Towards the apex the leaf becomes horny; sections show that this horniness is due to a thickening of the epidermal walls.

Sisyrinchium is another genus in which both ensiform and terete leaves occur. Fig. 27 shows the oval ribbed limb of $S . j u n c e u m$, E. Mey. $;^{1}$ it may be compared with the phyllode of Acacia teretifolia, Benth. (Fig. 28). The resemblance is remarkably exact, the vascular strands showing a close approximation in number and distribution.

In the genera Trimezia and Bobartia the occurrence of cylindrical junciform leaves has also been described. ${ }^{2}$

(ii) Transitional and bifacial leaf-types in Iris and Moraea.

The Irises to which I have hitherto referred are characterized by the unimportance of the leaf-sheath as compared with the limb-at least in the mature leaves-but in the bulbous Irises of the Section Xiplizum, the sheath takes a more prominent place. In Iris xiphioides, Ehr., the English Iris, there is a cylindrical limb (pet.), usually of some length (Fig. $3^{\mathrm{I}} \mathrm{A}$ ), but which may be reduced to a mere trace (Fig. $3^{I}$ B). I regard such a leaf as a leaf-base $(s h$.) crowned by a petiole, which may be either well developed or vestigial. The evidence on which such a view can be based is set forth in a previous paper, ${ }^{3}$ in which I have shown that the leaves of certain species of Tulipa, Hyacinthus, \&c., terminate in a cylindrical apex, which by analogy with the transitional forms between the mature leaf and the bud-scale in the Dicotyledon Fatsia, I interpret as petiolar. In Iris xiphioides we have a leaf of similar morphology, which, however, reveals its nature much more obviously. The apical region of 1 . xiphioides is approximately cylindrical, and its anatomy is so nearly radial that, if transverse sections be taken through it above the sheath, it is impossible to be certain about the orientation from internal evidence. In Fig. 3 I D, however, the section passes through the extreme top of the junction of sheath and limb, where the last trace of the sheath cavity, sh., indicates which side is adaxial.

The related species, Iris Xiphium, L., the Spanish Iris, is significant because the apical limb is but little modified from the ensiform type (Fig. 32 B). Mr. W. R. Dykes ${ }^{4}$ has pointed out that Iris spuria closely resembles $I$. Xiphizum in floral characters. It is interesting to find that his idea of a possible relationship between these two species, and, through them, of a connexion between the Apogon and Xiphium Sections, is confirmed by the evidence of the leaf structure; the limb of $I$. Xiphium (Fig. $3^{2} \mathrm{~B}$ ) is of a type which would be easily derivable from that of $I$. spuria (Fig. 8, p. 304). The facts of geographical distribution put no difficulty in the way of

1 See Arber, A. (1918), Fig. 16 B, p. 483 , for a more cylindrical leaf-type belonging to the same genus.
2 Ross, H. (1892-3)
S Arber, A. (19201).
- Dykes, W. R. (1913). 


\section{$\frac{\text { Leaves of Ins }}{\text { (Sections,Xiphium and Juno) }}$}

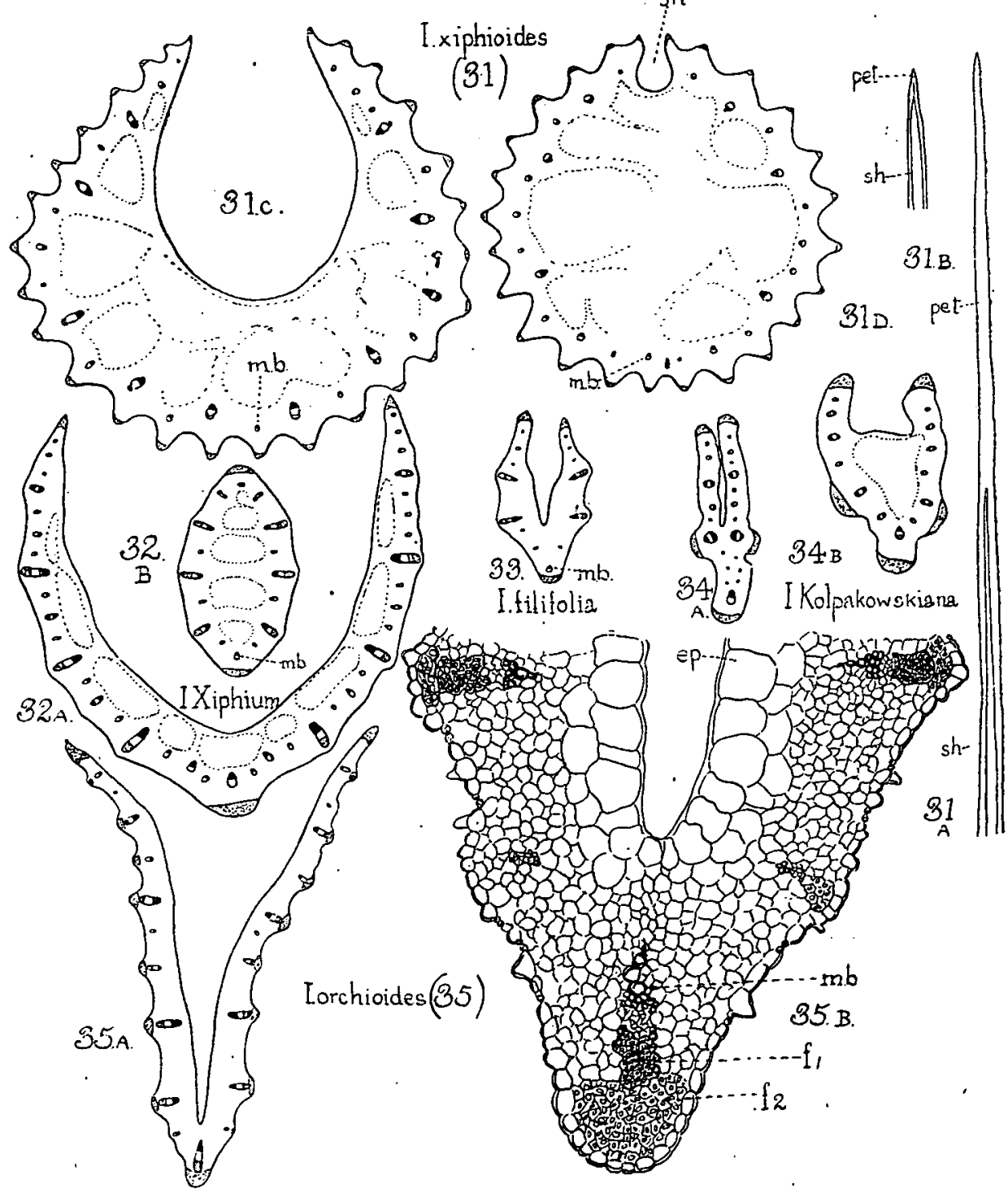

FIGS. 31-5. Figs. 3I A-D, Iris xiphioides, Ehr.; Figs. $31 \mathrm{~A}$ and B, apical region of two leaves seen from ventral side $\left(x \frac{1}{2}\right)$ to show variation in length of cylindrical apex (pet.) which terminates the bifacial region (sh.); Fig. $31 \mathrm{C}$, transverse section bifacial region $\left.(X)_{4}\right)$; Fig. $31 \mathrm{I}$, transverse section limb at uppermost limit of junction of sheath $(s h$.) and limb $(\times 14)$. Figs. $32 \mathrm{~A}$ and B, I. Xiphium, L.; Fig. $32 \mathrm{~A}$, transverse section sheath; Fig. $32 \mathrm{~B}$, transverse section apical limb; ( $\times{ }_{14}$ ). Fig. 33, I. flifolia, Boiss. ( $\times 11$, circa). Figs. 34 A and B, I. Kolpakowskiana, Regel; Fig. 34 A, transverse section leaf $(x 23)$; Fig. 34 B, transverse section nearer apex $(x 24$, circa); the epidermis is thickened and papillose, but this is not shown in these diagrams. Figs. $35 \mathrm{~A}$ and $\mathrm{B}$, $I$. orchioides, Carr.; Fig. $35 \mathrm{~A}$, transverse section leaf $(\times 14)$; Fig. $35 \mathrm{~B}$, midrib region of Fig. 35 A ( $\times 77$, circa). Note contrast between lignified fibres, $f_{1}$, and non-lignified bypodermal fibres, $f_{2}$. 
accepting Mr. Dykes's view, since Irises of the Spuria group are found over the whole range of $I$. Xiphium.

In Iris filifolia, Boiss., another of the Xiphium Section, the only leaf which I was able to cut had no cylindrical apical region, but it was probably exceptional in this respect. ${ }^{1}$ Here, as in the other members of the Section which I have examined, the median bundle is less conspicuous than the main laterals (Fig. 33, p. 3I 3 ).

The rare species, $I$. Kolpakowskiana, Regel, ${ }^{2}$ whose affinities are somewhat uncertain, is generally associated with the Xiphium Section. Its leaf is described as Crocus-like in external appearance, but the similarity is in reality quite superficial (contrast Figs. $34 \mathrm{~A}$ and $\mathrm{B}$ with Fig. $5^{6} \mathrm{I}$, p. $3^{24}$, representing the limb of Crocus Tomasinianus). The leaf is grooved on the adaxial side to the very apex; it may be regarded as consisting primarily of leaf-sheath, but as including towards the apex the region of transition to the petiolar limb which has itself been lost. It bears a certain resemblance to the dorsiventral region of the leaf of Iris filifolia. This resemblance is not, however, very close, and the median bundle is more developed than is usual in the Xiphium Section. In this point the leaf rather recalls the Irises of the Juno Section. As $I$. Kolpakowskiana is confined to Turkestan, it would seem more probable that its affinities would be with the Juno Irises, which range from the Mediterranean region to the Northwest Indian frontier, than with the Xiphiums, which are restricted to Spain and North-west Africa; but it is evidently a somewhat isolated form.

The Juno Irises differ from the general Xiphium type in being dorsiventral to the extreme apex; that is to say, the leaf is, on my view, more reduced than that of the Xiphizm Section, and consists merely of leaf-sheath, having lost all trace of the petiole in which it once terminated. The leaves of the Juno Irises may be somewhat sharply folded along the midrib, which is, as a rule, at least as important as the main laterals. Iris orchioides, Carr. (Figs. $35 \mathrm{~A}$ and $\mathrm{B}$ ) is a typical example. It shows very distinctly the difference between the lignified fibres $\left(f_{1}\right)$ associated with the phloem, and the non-lignified hypodermal fibres $\left(f_{2}\right)$ which lie between the $\left(f_{1}\right)$ group and the epidermis. Chodat and Balicka-Iwanowska " have shown that the presence or absence of these hypodermal fibres is a character of considerable systematic importance.

In the closely related genus Moraea we find parallels both for the ensiform and bifacial leaves of Iris. The Section Eumoraea (Dietes) contains ensiform leaves, such as those of Moraea.Macleai, Hort. (Fig. 12, p. 304), and $M$. Robinsoniana, C. Moore et F. Muell. (Fig. I I, p. 304), which recall those of the Irises of the Apogon Section, \&c. But we also meet with a type of leaf which resembles that of the Xiphium Section in being

\footnotetext{
1 Goebel, K. (1913), p. 285 .

2 Hooker, I. D. (1880).

Chodat, R., and Balicka-Iwanowska, G. (1892).
} 


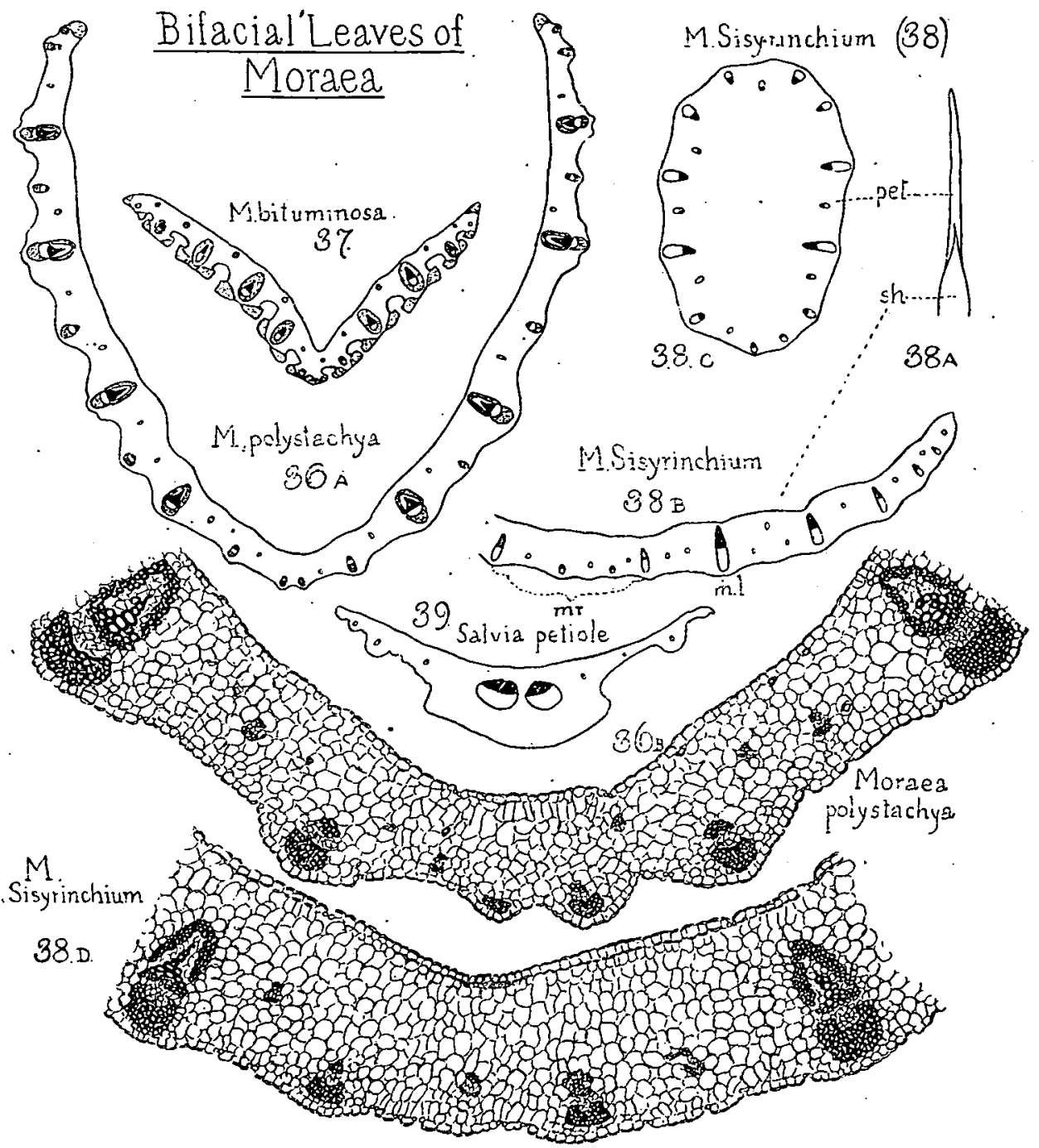

Figs. 36-9. Fig. 36, Moraea polystachya, Ker-Gawl.; Fig. $3^{6} \mathrm{~A}$, transverse section leat $\left(x_{1}\right)$; Fig. $3^{6}$ B, transverse section midrib region of another leaf $(x 47)$. Fig. 37 , M. bituminosa, Ker-Gawl., transverse section leaf ( $x$ 14). Fig. $3^{8}, M$, Sisyrinchizem, Ker-Gaul.; Fig. $3^{8}$ A, leafapex seen from the ventral side $\left(x \frac{1}{2}\right)$ to show solid apex, pet., and bifacial region, sh.; Fig. $3^{8} \mathrm{~B}$, transverse section (incomplete) of bifacial region of leaf $(x 14) ; m . r$, midrib region; m.l., main

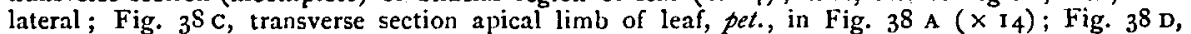
transverse section midrib region indicated by bracket in Fig. $38 \mathrm{~B}(\times 47)$. Fig. 39, Salvia Verbctaca, L. (Labiatae) transverse section petiole $(x .14)$ to show absence of median bandle.

prevailingly dorsiventral, but terminating in a solid monofacial apex. ${ }^{1}$ Figs. 37 and 36 show sections of the bifacial leaves of $M$. bituminosa, Ker-Gawl., and $M$. polystachya, Ker-Gawl. Balicka-Iwanowska ${ }^{2}$ states that,

$$
\text { I Ross, H. (1822-3). }
$$

2 Balicka-lwanowska, G. (1892-3). 
in $M$. polystachya, opposite the larger bundles there are smaller bundles inversely orientated. I am unable to confirm this description; I find the bundles to be all normally orientated and arranged in a single series.

The most striking peculiarity of the dorsiventral Moraeas is the unusual character of the midrib region. This region, in the species which I have examined, is thinner than the remainder of the leaf, and its bundles are smaller than the rest and somewhat irregularly placed. This feature is not confined to the dorsiventral species. Figs. I2 A and B, p. 304, show the absence of the median bundle in the ensiform $M$. Macleai; the shape of the leaf of this species makes the lack of midrib even more conspicuous than in the bifacial forms.

The genus Moraea differs from Iris chiefly in the absence of a perianthtube and the fact that the stamens generally cohere. It is commonly said that the Moraeas are found to the south and the Irises to the north of the Equator. But this can only be maintained if the Barbary Nut, Iris Sisyrinchizm, L., be ranked as a true Iris. This plant, which ranges from Portugal and Morocco to North-west India, resembles the Irises in possessing a perianth-tube, but in many other points recalls the Moraeas. Though Sir Michael Foster ${ }^{1}$ placed it unhesitatingly in the genus Iris, and both $\mathrm{Pax}^{2}$ in Engler's 'Pflanzenfamilien ' and Baker ${ }^{3}$ in the 'Handbook of the Irideae' take the same line, other authorities have long held that it ought to be regarded as a Moraea; it was figured as 'Moraea Sisyrinchium, the European Moraea ', in Curtis's 'Botanical Magazine' in I8I I (vol. xxxiii, No. I407). Mr. W. R. Dykes kindly tells me that his long study of the genus Iris has convinced him that this plant should be excluded from the genus and transferred to Moraca, which it resembles in its corm and in the sheathing leaves of the inflorescence axis, while Ross ${ }^{4}$ and Chodat and Balicka-Iwanowska ${ }^{5}$ have reached the same conclusion from the leaf anatomy, which is the point that specially concerns us here. The leaf of the Barbary Nut (Fig. $3^{8 \mathrm{~A}}$ ) recalls some of the Moraeas in consisting of a flat bifacial region (leaf-base) terminating in a cylindrical apex (petiole). The apical appearance of the leaf exactly corresponds, for instance, to that of Moraea edulis, Ker-Gawl., as figured in Curtis's 'Botanical Magazine', vol. xvii, No. 6I3. The internal structure is shown in Figs. $3^{8} \mathrm{~B}-\mathrm{D}$, and it will easily be seen that in the anatomy-especially in the peculiarities of the midrib region-there is an exact reproduction of the features of such a species as Moraea polystachya (Figs. $3^{6} \mathrm{~A}$ and $\mathrm{B}$ ). The leaf structure thus tends to confirm the attribution to Moraea.

\footnotetext{
1 Foster, M. (1892).

s Baker, J.G. (1892).

2 Pax, F. (1888).

B Chodat, R., and Balicka-Iwanowska, G. (1892). 


\section{Leaves of the IXIOIdeae and Phyllodes of $A C A C I A$.}

I showed in the genus Iris that the phyllodic leaves range from the vertical ensiform type to the curious 'radial', angular, or ribbed forms of Iris reticulata, \&c. A corresponding range is characteristic of the Ixioideae. We find a series beginning with typical equitant leaves, such as those of Sparaxis (Fig. 40. p. 318), Antholyza (Fig. 49), and certain species of Gladiolus (Figs. 43 and 44), which can be closely paralleled with the phyllodes of such Acacias as $A$. uncinella, Benth. (Fig. 42), and $A$. neurophylla, W. V. Fitz. (Fig. 4I). The pseudo-midrib ${ }^{1}$ (p.m.r.), formed from the two main lateral veins, is a striking common character of these Irid and Acacia leaves. In addition to the ensiform species, we have also, in the genus Gladiolus itself, certain more aberrant forms which may be regarded as developments from the type. Gladiolus ornatus, Klatt, for instance (Fig. 45 B), has a leaf in which the ensiform character is becoming modified, and which shows a close resemblance to the phyllode of Acacia incurva, Benth. (Fig. 46). Gladiolus tristis, L., is a still more remarkable example, which departs to an extreme degree from the usual equitant type ; the cruciform section of the limb (Fig. $4^{8} \mathrm{~J}$ ) does not at first sight suggest a leaf at all. Fig. 48 A shows a plant of Gladiolus tristis with a number of young shoots. . These each beair a succession of scale leaves $\left(s c_{c_{1}}, s c_{.2}, s c_{._{3}}\right)$ followed by a foliage leaf $(f . l)$ indicated in.black. The clue to the peculiarities of the leaf structure is to be found in a study of the transition from the basal sheathing region to the limb. Figs. $48 \mathrm{~B}-\mathrm{E}$ show this transition in the case of the tallest foliage leaf $(f . l$.$) in Fig. 48$ A. At the base the leaf forms a continuous sheath (Fig. $4^{8} \mathrm{~B}$ ), which is ridged and furrowed, the ridges coming opposite to. the bundles. A little higher, the sheath becomes open, and the ridges associated with the midrib and main laterals begin to predominate; the subsidiary ridges $\left(r\right.$. and $r^{\prime}$.) have altogether vanished at the higher levels represented in Figs. $48 \mathrm{D}$ and $\mathrm{E}$, their place being taken by the grooves $g$. and $g^{\prime}$. At the same time the margins of the sheath have fused, and are represented by the fourth main ridge opposite the midrib. Figs. 48 F-J show a series of sections through another leaf, in which the loss of the subsidiary ridges $r$. and $r^{\prime}$. can be followed somewhat 'more easily than in the preceding series, and in which the ultimate form of the limb (Fig. $48 \mathrm{~J}$ ) is also included. In connexion with each of the four main ridges a pair of lateral keels or wings ( $k$. and $k^{\prime}$. in Figs. $48 \mathrm{H}-\mathrm{J}$ ) are developed; these wings are supplied by small vascular strands. The outstanding feature of these series of sections through the leaves of Gladiolus tristis is that the structure of the basal region of the limb (Figs. $48 \mathrm{D}, \mathrm{E}$, and $\mathrm{I}$ ) at once suggests that we are dealing with a cylindrical petiolar phyllode, merely modified by four deep invaginations or grooves, associated with slight lateral wings;

1 'Côte médiane' of Chodat, R., and Balicka-Iwanowska, G. (1892). 


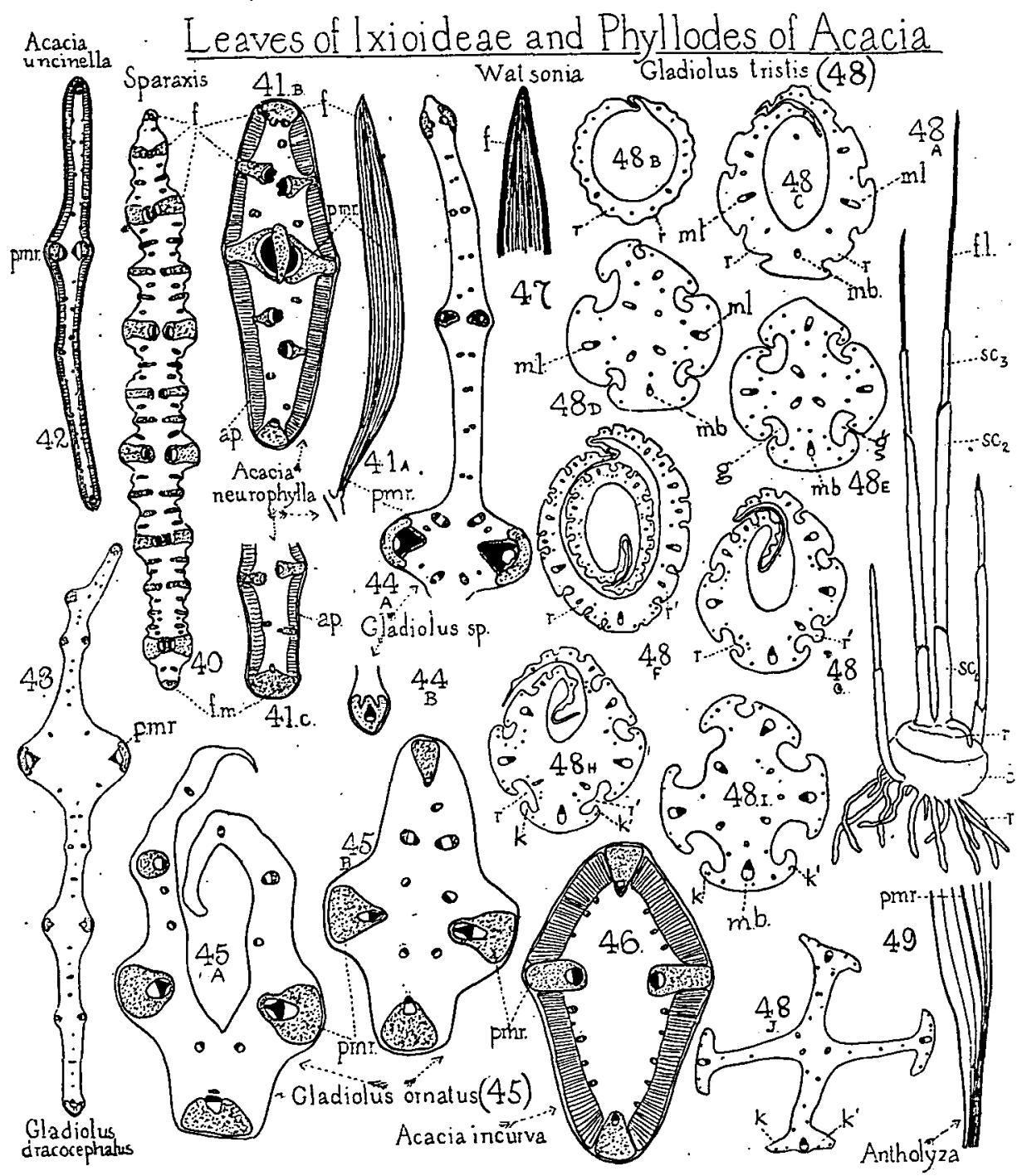

Figs. 40-9. (Throughout, p.m.r., pseudo-midrib; f., fibres; f.m., fibrous margin.) Fig. 40, Sparaxis pulcherrima, Hook. ( $\times 14$ ). Fig. 4I, Acacia nezurophylla, W. V. Fitz.; Fig. 4 I A, phyllode $\left(x \frac{1}{2}\right)$; Fig. $4^{\mathrm{I}} \mathrm{B}$, transverse section phyllode not far from base, two upper bundles not yet united ( $\times$ I 4 ); a.p., assimilating parenchyma; Fig. 4 I C. margin of a similar phyllode (whether dorsal or ventral uncertain) to show great development of fibres in proportion to vascular tissue. Fig. 42, Acacia uncinclla, Benth., phyllode (x I4). Fig. 43, Gladiolus dracocephalus, Hook. ( $\times$ 14). Fig. 44, Gladiolus sp.; Fig. 44 A, adaxial side of limb to show fibrosis of pseudo-midrib and of ventral margin ( $\times 14)$; Fig. $44 \mathrm{~B}$, dorsal margin of sheath region to show fibrosis $(\times 47)$. Fig. 45, Gladiolus ornatus, Klatt $(x 47)$; Fig. 45 A, sheath; Fig. 45 B, limb. Fig. 46, Acacia incurva, Benth., transverse section phyllode $\left(x_{23}\right)$ for comparison with Fig. 45. Fig. 4\%, apex of leaf of Watsonia marginata, Ker-Gawl. ; fibrous rim, $f$, which is bright yellow in herbarium material, indicated in black $\left(\times \frac{1}{2}\right)$. Fig. $4 \delta$, Gladiolus tristis, L.; Fig. $48 \mathrm{~A}$, young plant $\left(\times \frac{1}{2}\right) ; s C_{.1}, s c_{.2}, s C_{3}$ successive scale leaves; f.l., foliage leaf; $c$. , corm; $r$., roots. (Brown scale leaves have been removed from corm.) Figs. 48 B-E, series of transverse sections from base upwards through tallest leaf in Fig. $48 \mathrm{~A},(\times 23) ; r$., subsidiary ridges; $g$., grooves; $m . l$., main lateral bundles; Figs. ${ }_{4}^{8} \mathbf{F}-\mathrm{J}$, similar series through another leaf $\left(x 1_{4}\right) ; k$. and $k^{\prime}$., keels; $r$. and $r$., subsidiary ridges. Fig. 49, Antholysa nervosa, Thunb., junction of top of sheath and base of limb $\left(\times \frac{1}{2}\right)$ : 
I think that the comparison with other Irids supports this interpretation. In the upper part of the limb (Fig. $4 \delta \mathrm{J}$ ) the invaginations have become so deep that, if we only knew the leaf in this region, its phyllodic character might easily be overlooked.

The sheath of Gladiolus iristis, with its ridged and furrowed dorsal surface (Fig. $4^{8 . F}$ ), is an instance of a type of structure which occurs repeatedly in this family, and to which I shall refer again (p. 332) when considering the general question of the evolution of the Irid leaf.

\section{Fibrosis in IRIDS and ACACIAS.}

An exaggerated degree of development of the fibrous strands in the leaf is characteristic of many of the Iridaceae. In certain cases the survival of these strands, especially in the basal region, provides a corm-sheath, which is sometimes continued upwards as a tuft of fibres. The most striking instance I have seen is Antholyza nervosa, Thunb., in which, in the case of a specimen at the flowering stage in the British Museum herbarium, the fibres are as much as $28 \mathrm{~cm}$. long.

In the individual leaf, the fibrous strands generally run parallel to the bundles, between the phloem and the leaf-surface, but they may also surround and enclose the bundles. In the ensiform leaf-types they are most conspicuously developed at the dorsal and ventral margins. The fibrous rim thus produced - which is rounded in section and often, in herbarium material, bright yellow, polished, and enamel-like-is characteristically confined to the limb of the leaf, and absent from the sheath; it occurs, that is to say, in the nember which I interpret as a petiolar phyllode, but not in the leaf-base. Watsonia marginata, Ker-Gawl. (Fig. 47), is the most striking instance I have seen; here, both on the dorsal and ventral side, the rim begins abruptly at the junction of sheath and limb. There are also many noticeable cases of marginal fibres in the genus Gladiolus (Figs. 43 and 44), e.g. G. Ludwigii, Pappe, and G. crassifolius, Baker, while various Irises (e. g. Iris verna, L., and I. Donglasiana, Herb., Fig. 9, p. 304), Moraea Robinsoniana, C. Moore et F. Muell. (Fig. I I, p. 304), Cypella coriifolia, Baker, and some Patersonias, show the same characteristic in varying degrees.

From the standpoint of the phyllode theory, the most suggestive feature about the fibrosis of the Irid leaf is the way in which it can be paralleled among the Acacias. The phyllode of Acacia neurophylla, W. V. Fitz. (Fig. 4I B), for instance, has a dorsal and ventral fibrous rim, essentially similar to that of a Gladiolus or a Watsonia. The comparison of Figs. 40, 41, 44, and 47 will show the general agreement of the marginal -structure in the two families. The margin of a phyllode seems more liable to fibrous thickening than that of a lamina, possibly because the latter is characteristically' attenuated, while the former-not being a true margin, 
but representing merely the dorsal or ventral crest of a flattened petiolenaturally tends more to massiveness.

Not only marginal but also apical fibrousness is a common character of Irids and Acacias; the indurated apices of certain 'radial' Acacia phyllodes may be compared with the horny leaf-tips of Iris reticulata.

It is scarcely possible to cut many sections of the' strongly fibrous leaves of Acacias and Irids without being impressed by the apparently excessive character of the fibrosis-excessive, that is to say, from the point of view of any purpose which it may conceivably serve in the plant's economy. The most reasonable view appears to be that the fibrosis is a process outside the plant's control, which may almost be treated as a pathological result of unsuitable conditions. Dr. A. H. Church ${ }^{1}$ has rectently suggested that the xerophyte is, as it were; embarrassed by excess of waste polysaccharides, and deposits them on its cell-walls simply to get rid of them. The conditions which bring about this excess are, on his view, the disturbance of the balance between photosynthesis and proteid synthesis, due to the inadequacy of the transpiration stream in relation to the available sunlight. The common association of fibres and phloem, and the fact that fibrosis tends to increase towards the leaf apex (e.g. Crocus vermus, Fig. 57 B and C., p. 324, and Hermodactylus tuberosus, Fig. 29 E, p. 31 I), may perhaps be regarded as affording some indirect support to Church's view. If his theory be accepted, any utility which may be attributed to the fibres must be regarded as an entirely secondary matter.

\section{Foliated Leaves in the Iridoideae and Ixioideae.}

Some of the most aberrant leaf-types met with in the Iridaceae are those, for which the names 'folia tabulata' and 'mehrflächige Blätter' have been suggested, and which I propose here to term 'foliated leaves'. As Lindman ${ }^{2}$ rightly points' out, these leaves do not differ fundamentally from the ensiform type, though they have been in many cases modified almost out of recognition. The least modified form is perhaps that met with in Babiana (Ixioideae). Fig. $50 \mathrm{~A}$ shows a typical plant belonging to this genus. The earlier leaves $\left(r . l_{1}, r . l_{l_{2}}, r . l_{._{3}}\right)$ consist chiefly of sheath, with a minute limb in the case of $r . l_{._{2}}$ and $r . l_{.3}$. In the typical foliage leaves $l_{\cdot 1}, l_{r_{2}}$, and $l_{\cdot_{3}}$ the limb becomes more and more conspicuous, while the sheath at first sight suggests a petiole. It is by no means rare in Monocotyledons to find that the ancestral loss of the leaf-blade, and the compensatory development of the petiole as a 'pseudo-lamina', 3 is associated with the assumption by the sheath of petiole-like functions. Fig. $50 \mathrm{G}$ shows the truncated form of the limb in another species,
1 Church, A. H. (1919).
2 L.indman, C. A. M. (1899).
Arber, A. (1918). 


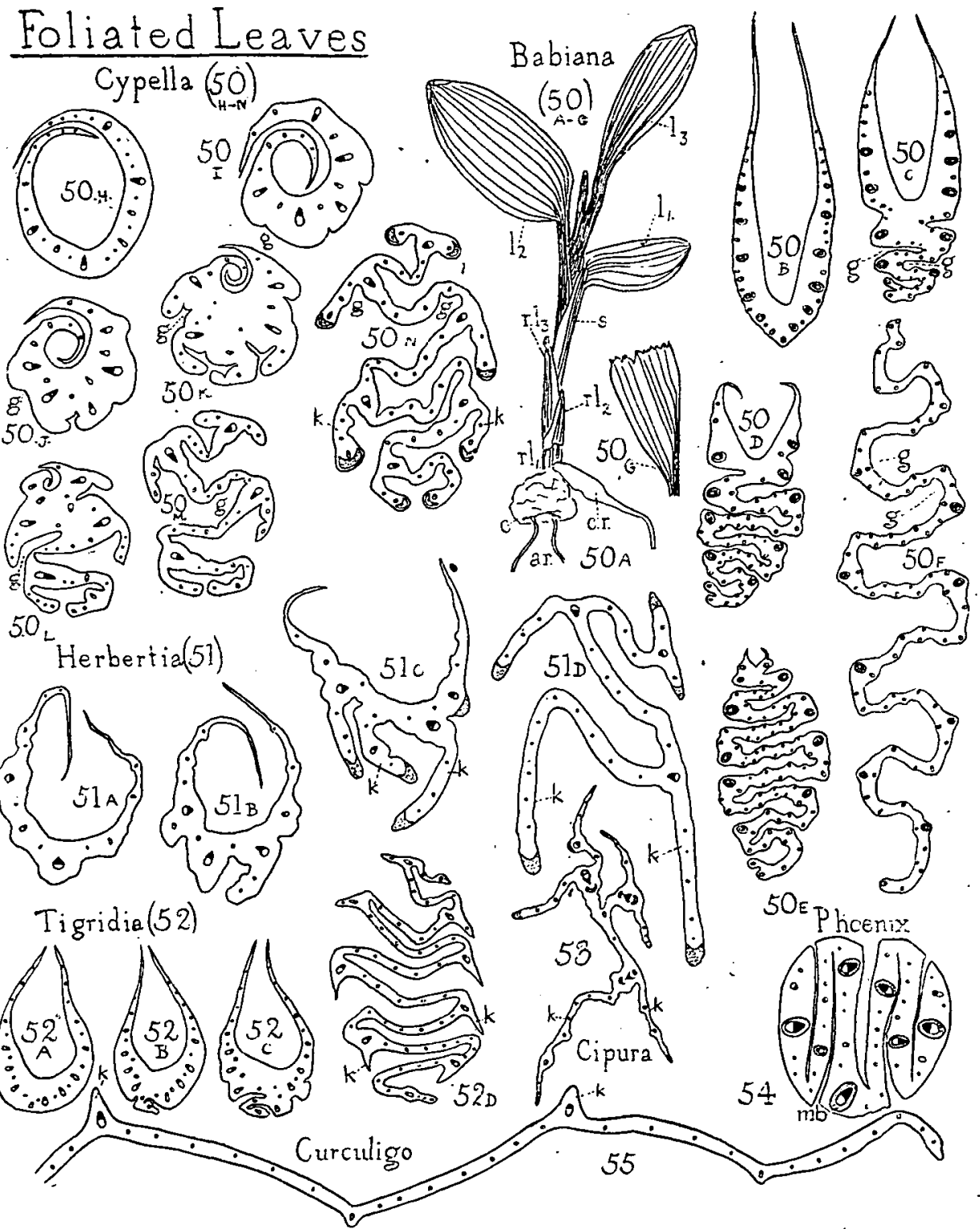

FIGS. 50-5. (Throughout, g., groove; k., keel). Figs. 5० A-G, Babiana; Fig. 50 A, Babiana sp., young plant $\left(\times \frac{1}{2}\right) ; c$. , corm; a.r.; absorptive roots; $c . r$. , contractile root; $l_{.1}, l_{.2}, l_{.3}$, normal leaves; s., leal sheath; r.l.1, r.l. ${ }_{2}, r_{. l_{3}}$, reduced leaves; Figs. $5 \circ \mathrm{B}-\mathrm{F}$, series of transverse sections through junction of sheath and limb of $l_{.3}$ in Fig. $50 \mathrm{~A}\left(\mathrm{X}_{14}\right)$; Fig. $50 \mathrm{G}$, Babiana cuneifolia, Baker, limb and upper part of long leaf-sheath $\left(x \frac{1}{2}\right)$. Figs. $50 \mathrm{H}-\mathrm{s}$, Cypella Herberti, Herb. $(\times 14)$; Figs. $50 \mathrm{H}-\mathrm{M}$, series of transverse sections through junction of sheath and limb in one leaf ;

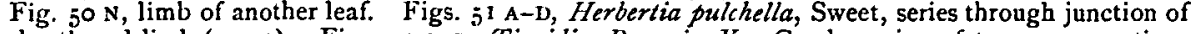
sheath and limb $(\times 23)$. Figs. 52 A-D, Tigridia Pavonia, Ker-Gawl, series of transverse sections through junction of sheath and limb $(\times 7)$. Fig. 53, Cipura paludosa, Aubl., transverse section $\operatorname{limb}(x+4)$. Orientation uncertain, as only a fragment of the limb was available. Fig. 54, Phoenix dactyliferc, L., transverse section near base of first foliage leaf $(x 14)$ to show 'folding'. Fig. 55, Curculigo sp., transverse section small part of limb near margin; leal can be folded up like a fan ( $\times 14)$. 
Babiana cuneifolia, Baker. The leaf-limb in this genus gives, at first glance, the impression of being folded in a fan-like fashion, but this impression is shown to be incorrect when a series of sections is cut through the junction of sheath and limb. Figs. $50 \mathrm{~B}-\mathrm{F}$ represent such a series for the case of leaf $l_{3}$ in Fig. $50 \mathrm{~A}$. Fig. 50 B shows the sheath region, which is quite normal. In Fig. $50 \mathrm{C}$ the limb is beginning to put in an appearance, but it is modified from the ensiform type by deep grooves or invaginations $(g$.$) , which occupy alternating positions to right and left. As we leave the$ sheath region, the grooves become more conspicuously developed (Figs. $5^{\circ}$ $\mathrm{D}$ and $\mathrm{E}$ ) until in Fig. $5 \circ \mathrm{F}$ the mature form is reached. These sections show plainly that-as Lindman ${ }^{1}$ has already pointed out-the terms "feuilles plissées' ${ }^{2}$ and 'foglie piegate', ${ }^{3}$ which have been suggested for these leaves, are inadmissible. We are not dealing with a case of 'folding', but of invagination, which is an entirely different thing. The difference is, in fact, as fundamental as that recognized by the geologist between the case of the production of certain mountain ranges by the actual wrinkling of the earth's crust, and the case of the carving of a.system of hills and valleys, by the action of rain and rivers, out of an originally flat surface. For comparison I have included Fig. 54-a section of the basal region of a leaf of Phoenix dactylifera, L. (Palmae)-since this leaf has been described as offering a genuine instance of folding. It will be seen from this figure that, if the leaf were flattened out, all the bundles would be normally orientated, with xylem upwards and phloem downwards: And I have also found the same thing to be true of the 'plicated ' leaves of Curculigo sp. (Amaryllidaceae, Fig. 55) and Carludovica Plumerii, Kunth. (Cyclanthaceae). But, on the other hand, if the leaf of Babiana be flattened, the bundles will still be orientated in two opposite ways, as in so many other phyllodes. I propose in later papers to consider the nature of the 'folded' leaves of the Palms, Cyclanthaceae, Curculigo, \&c., and to discuss the relation of these leaves to those of the Irids.

Tigridia (Iridoideae, Figs. $52 \mathrm{~A}-\mathrm{D}$ ) may be taken to represent a further stage in the evolution of the foliated leaf. The transition region between sheath and limb shows that pseudo-plication arises exactly as in Babiana, through lateral invaginations. The form is, however, rendered a little more complicated by the development of a slight keel, $k$, from the leaf surface in the region outside the phloem of each of the main bundles; this keel may itself contain a bundle. Similar keels are also occasionally developed in non-foliated leaves. They may, for instance, occur in connexion with the midrib of an ordinary ensiform leaf, such as that of Tritonia ${ }^{4}$ or with the angles of a tetragonal leaf, such as that of Hermodactylus (Fig. 29 D,

1 Lindman, C. A. M. (1899).

2 Chodat, R., and Balicka-Iwanowska, G. (1892).

3 Ross, H. (1892-3).

- Arber, A. (1918), p. 486 , and Figs. $\mathbf{I}_{5}$ B and c, p. $4^{8} 3$. 
p. $3^{1}$ I), while-outside the Iridaceae-non-vascular keels are associated with the main bundles of the plicate leaf of Curculigo (Fig. 55).

A further stage in the complexity of the foliated leaf is reached in Cypella (Figs. $5^{\circ} \mathrm{H}-\mathrm{N}$ ), Herbertia (Alophia ${ }^{1}$ ) (Figs. 5I, A-D), and Cipura (Fig. 53), all belonging to the Iridoideae. Here the keels $\left(k ., k^{\prime}\right.$., \&c.) are developed into conspicuous lamellae, supplied by a number of bundles, and usually standing out at right angles to the plane of symmetry of each of the main vascular strands. Cypella Herberti, Herb., is of special interest in connexion with the phyllode theory, because, just at the junction of sheath and limb, the outline of the transverse section is almost circular (Fig. $50 \mathrm{~K}$ ). At this stage the leaf is not unlike that of Gladiolus tristis at a corresponding level (Fig. $48 \mathrm{D}, \mathrm{p} .318$ ). The study of the transition from sheath to limb thus removes any difficulty which might have been felt in visualizing the limbs of both these leaves as cylindrical petioles, which at the extreme base retain some approximation to a typical petiolar. structure, but higher up become rapidly modified. The final form to which the limbs attain is markedly different in the two cases (cf. Fig. $5^{\circ} \mathrm{N}$, and Fig. 48 J, p. $3^{I} 8$ ). Their ultimate differences depend upon the fact that Gladiolus tristis has only four grooves, arranged as two symmetrical pairs, while each, main bundle is associated with two lateral wings, whereas Cypella Herberti is less symmetrically modified-the grooves, which are more numerous, are placed alternately, and there is only a single wing in connexion with each main bundle.

\section{The Leaves'of the Crocoldeae.}

While the Iridoideae contains 35 , and the Ixioideae I 8 genera, the third tribe of the Iridaceae, the Crocoideae, includes only the fourRomulea, Crocus, Syringodea, and Galaxia. ${ }^{2}$ We may first consider the two larger genera, Romulea and Crocus. Of these Romulea has by far the more extensive distribution; it is found in the Mediterranean region and also in Africa (including South Africa), while in the other direction it even extends into England-R. Columnae, Sebast. et Mauri, occurring near Dawlish. The genus Crocus, on the other hand, is not represented outside the Mediterranean region. The distribution thus indicates that Romulea is probably the older type, and certain structural features tend to support this view. For instance, the extreme reduction of the whole Crocus plant ${ }^{3}$ and the length of the flower-tube may be regarded as characters in which the genus has progressed farther than Romulea on the path of specialization. The leaf of Romulea also diverges less from the average Irid type than does

1 This case has been studied in detail by Lindman, C. A. M. (1899).

2 Pax, M. (1888), and Baker, J. G. (1892). It is possible that Galaxia ought to be transferred to the Iridoideae; see p. $3^{28}$.

${ }^{3}$ Church, A. H. (1908). 


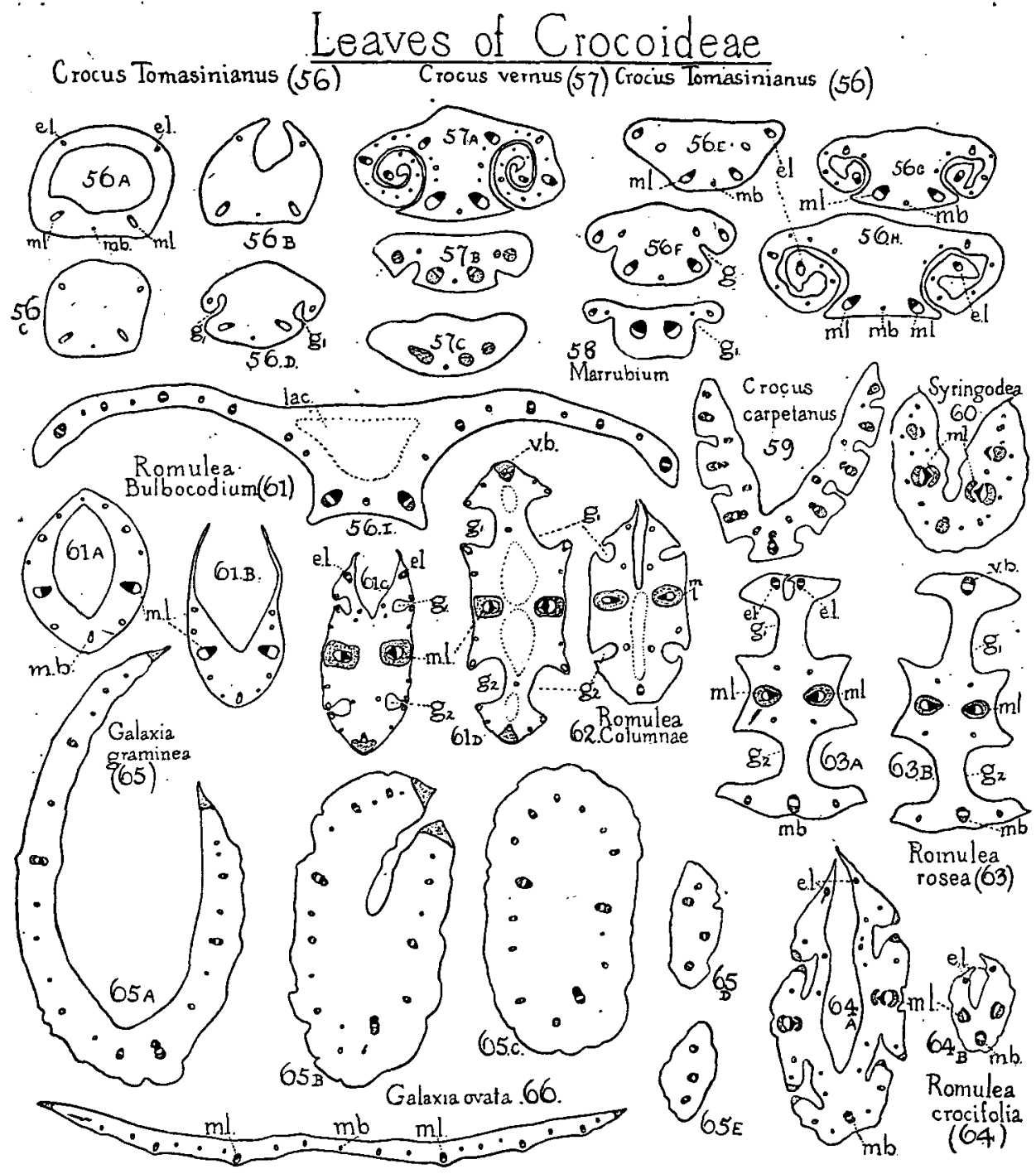

FIGS. 56-66. (Throughout, m.l., main lateral bundle ; e.l., external lateral bundle ; v.b., ventral bundle; $g_{1}$ and $g_{2}$, grooves ; lac., lacuna.) Figs. $56 \mathrm{~A}-1$, Crocus Tomasinianus, Herb. ; Figs. 56 A-D, sections from microtome series through transition from sheath to limb in first foliage leaf of seedling $(x 47)$; Figs. $56 \mathrm{E}-\mathrm{I}$, series of transverse sections through leaf of mature plant from near base upwards, not including sheath $(\times 23)$; Figs. $56 \mathrm{E}-\mathrm{H}$, basal region; Fig. 56 1, higher up. Fig. 57 , Crocus vernus, All.; Fig. $57 \mathrm{~A}$, transverse section at level corresponding to Fig. $56 \mathrm{H}$; Figs. $57 \mathrm{~B}$ and $c$, transverse section near apex $(\times 14)$. Fig. 58 , Marrubium velutinum, Sibth. et Sm. (Labiatae), transverse section petiole ( $x$ 14). Fig. 59, Crocus carpetanus, Boiss. et Reut., transverse section leaf $\operatorname{limb}(\times 23)$. Fig. 60, Syringodea bicolor, Baker, transverse section leaf limb $(x 23)$. Figs. 61 A-D, Romulea Bulbocodium, Sebast. et Manri, series of transverse sections through leaf $(x 23)$. Fig. 62, $R$. Columnae, Sebast. et Mauri, transverse section just at top of sheath ( $\times 23$ ). Fig. $63, R$. rosea, Eckl. ; Fig. $63 \mathrm{~A}$, transverse section just at top of sheath; Fig. $6_{3} \mathrm{~B}$, transverse section limb $\left(x_{23}\right)$. Fig. $64, R$. crocifolia, Vis. ; Fig. 64 A, transverse section leaf limb; Fig. 64 B, transverse section close to apex $\left(x 2_{3}\right)$. Figs. 65 A-E, Galaxia gramizea, Thunb., series of transverse sections from sheathing base to apex; possibly $65 \mathrm{D}$ and $\mathrm{E}$ are from a different leaf $\left(x_{2} 3\right)$. Fig. 66, Galaxia ovata, Thunb., transverse section limb of leaf ( $\left.\begin{array}{ll}x & 14\end{array}\right)$. 
that of Crocus. So it may be well to begin our consideration of the Crocoideae by trying to make out the nature of the leaf of Romulea, and then to consider the relation borne to it by the highly peculiar leaf of Crocus.

The leaf structure of Romulea is illustrated in Figs. 6I-4. R. Bulbocodium, Sebast. et Mauri, is a typical example. Here there is a sheath, closed at the base (Fig. 6I A), whose most striking feature is the relative unimportance of the median bundle (m.b.) as compared with the main laterals (m.l.). Higher up, the sheath opens out (Fig. 6I B) and the passage into the limb (Figs. $61 \mathrm{C}$ and $\mathrm{D}$ ) shows that the leaf is essentially of the ensiform type, not unlike that of Gladiolus ornatus (Fig. 45 B, p. $3^{\text {I } 8 \text { ), but }}$ modified by the presence of two pairs of grooves or invaginations, one pair $(g .2)$ lying between the median bundle and the main laterals, and the other pair $\left(\dot{g}_{v_{1}}\right)$ between the main laterals and the ventral bundle formed by the fusion of the external lateral bundles (e.l.). Romulea Columnae, Sebast. et Mauri (Fig. 62), and R. rosea, Eckl. (Fig. 63), do not differ essentially from the type of $R$. Bulbocodium. One member of the genus, however, $R$. crocifolia, $V$ is. (Figs. $64 \mathrm{~A}$ and $\mathrm{B}$ ), diverges from the $R$. Bulbocodium type in being dorsiventral to the extreme apex of the leaf. ${ }^{\prime}$ I interpret the leaf of this species as a reduced form, equivalent merely to the sheathing leaf-base of the other members of the genus, the petiolar limb having been lost. $R$.crocifolia thus bears the same relation to $R$. Bulbocodium that the Juno Irises bear to the Irises with ensiform leaves.

The leaf of Crocus is described by Ross ${ }^{2}$ as belonging to the dorsiventral type, and is compared by him to the aberrant Romulea crocifolia. Čelakovský ${ }^{3}$ and Velenovský ${ }^{4}$ take the same view, while Chodat and Balicka-Iwanowska ${ }^{5}$ expressly state that the leaf of Crocus is in no way comparable with that of a normal Romulea, and Balicka-Iwanowska, ${ }^{6}$ in her later paper, describes it as 'absolutely isolated among the Irideae'. My study' of the anatomy and mode of origin has, however, led me to a conclusion wholly different from that of these five writers; I hope to show that the limb of the Crocus leaf is a petiolar phyllode, strictly homologous with the leaf of such a Romulea as $\mathrm{R}$. Bulbocodium, though it is true that transverse sections of the mature leaves of the two genera (cf. Figs. $5^{6} 1$ and $61 \mathrm{D}$ ) would scarcely suggest the possibility of any relationship between them.

We may take Crocus Tomasinianus, Herb., as a case for description. Figs. $56 \mathrm{~A}-\mathrm{D}$ represent sections from a microtome series through the base

1 Ross, H. (1892-3), draws attention to the dorsiventral character of $R$. crocifolia, Vis. According to Béguirot, A. (1907-9), this specific name is merely a synonym of $R$. nivalis, Klatt, but judging from a leaf from Visiani's type specimen at Padua, generously sent to me by Professor Béguinot, $R$. crocifolia is more completely dorsiventral in structure than $R$. nivalis, and the leaf anatomy certainly suggests that a separate specific name might usefully be retained.

${ }^{2}$ Ross, H. (1892-3).

$\therefore$ Velenorskí, J. (1907).

$\therefore$ Balicka-Iwanowska, G. (1892-3).
3 Čelakovský, L. J. (1903).

s Chodat, R., and Balicka-Iwanowska, G. (1892). 
of the first plumular leaf of a seedling of this species. Near its attachment to the axis the sheath region is closed. This closed basal region, to which attention was long ago drawn by Irmisch, ${ }^{1}$ being extremely short, may easily be overlooked, and it is sometimes, indeed, not typically developed; in serial sections through two shoots of Crocus speciosus, Bieb., I found that inextricable confusion was produced by extreme telescoping of the internodes, associated with a fusion of the leaf-bases both with one another and with the axis. The vascular anatomy of the sheath in a plumular leaf of Crocus Tomasinianus is shown in Fig. $56 \mathrm{~A}$; the median bundle $(m . b$. is so slightly differentiated as to be scarcely visible, consisting at this stage of a few procambial cells only. The main laterals, on the other hand, are much larger, and their xylem and phloem can already be distinguished. A second smaller pair of bundles occurs, which we may call the external laterals $\left(e . l_{.}\right)$. A little higher up two invaginations $\left(g \cdot_{1}\right)$ come into existence between the main lateral and external lateral bundles. The further history of these grooves can be better followed in Figs. $5^{6} \mathrm{E}-\mathrm{I}$, which were drawn from a series of hand-sections through the base of a mature leaf of the same species. The invaginations, which are first. seen in Fig. $5^{6} \mathrm{~F}$, have developed farther in Figs. $5^{6} \mathrm{G}$ and $\mathrm{H}$, and the lateral wings, thus separated from the main part of the limb, increase greatly in length by intercalary growth, and become coiled. In Fig. $56 \mathrm{I}$ the final stage is reached-the unrolling of the two wings having produced the curious transverse section which characterizes the mature Crocus leaf. I have also studied the development of the leaf in Crocus biflorus, Mill., C. speciosus, Bieb., and $C$. vernuts, All. ${ }^{2}$ (Fig. 57), and I find that in each case the history is closely similar to that just traced for $C$. Tomasinianus. In Crocus vernus I followed the structure to the leaf-tip and fuund that at the apex the wings become reduced and the invaginations gradually die out (Figs. $57 \mathrm{~B}$ and C), so that there is an eventual return to something approaching the unmódified form of the limb.

When we turn to the comparison of Crocus and Romulea, we find that the leaves are really built on the same plan, with, however, two differences, which-though non-essential-result in a conspicuously different final form. In both genera we get a pair of grooves or invaginations $\left(g \cdot{ }_{\cdot 1}\right)$ arising between the main laterals $\left(m . l_{0}\right)$ and the external laterals $(e . l$.$) , but in Romulea there$ is an additional pair of grooves $\left(g \cdot{ }_{2}\right)$ lying between the median bundle and the main laterals ; this pair is unrepresented in Crocus. Again, in Romulea the external laterals (e.l.) approach one another and finally fuse to form a single bundle $(v . b$. in Figs. $61 \mathrm{D}$ and $63 \mathrm{~B})$, whereas the process of invagination and winging in Croczs carries the two external laterals far

1 Irmisch, T. (1850).

${ }^{2}$ Pax, F. (1888), figures the leaf of Crocus zernus as possessing no midrib: this, according to miy observations, is an error. 
apart, so that they are eventually separated by the entire width of the flat leaf. We have already shown that the leaf of Romulea is but little modified from the ensiform.type-that is to say, it is easily derivable from the most widespread form of petiolar phyllode. If my interpretation of the limb of Crocus, as precisely equivalent to that of Romulea, be accepted, the Crocus leaf must also come into the category of petiolar phyllodes; indeed, apart from the comparison with Romulea, the structure of the Crocus, leaf, considered in itself, carries indications that this point of view is not too far-fetched. Fig. $56 \mathrm{C}$ shows how petiole-like is the stage passed through just above the sheath region of the first plumular leaf in $C$. Tomasinianus. A comparison of Fig. $5^{6} \mathrm{~F}$ and Fig. 58, again, reveals how closely the stage at which the invagination is just beginning may be compared: with a certain Dicotyledonous petiole, that of Marrubium velutinum, Sibth. et $\mathrm{Sm} . ;^{1}$ we even get a corresponding grooving and the same conspicuous pair of main laterals; but whereas the median bundle in Crocus is present, though extremely reduced, in Marrubium it is altogether absent.

With minor variations, the type of leaf described seems to be universal in the genus Crocus, except in the case of two species confined to Spain, C. carpetanis, Boiss. et Reut., and C. nevadensis, Amo et Campo. ${ }^{2}$ I have not been able to get material of $C$. nevadensis, but $I$ have cut sections of C. carpetanus, which has a leaf differing conspicuously from that of a typical Crocus. There is a closed sheath at the base, which passes into a somewhat asymmetrical bifacial leaf, traversed by a series of bundles, alternately large and small; the dorsal surface is ridged opposite each of the larger bundles (Fig. 59). . The median bundle is not, as in the other Crocuses, smaller than the main laterals. This leaf I regard as morphologically a leaf-sheaththe petiolar limb of the other species of Crocus being unrepresented. But it is very different even from the sheath region of the other Crocuses, and rather recalls such leaves as that of Moraea bituminosa (Fig. 37, p. $3^{\mathrm{I}} 5$ ). The curious isolation of the leaf anatomy, in association with certain other aberrant features of the plant to which Maw draws attention, arouses some doubt as to whether the inclusion of $C$. carpetanus in the genus Crocus can be justified.

The small genus Syringodea, which is confined to the Cape, resembles Crocus and differs from Galaxia and Romulea, in having no above-ground stem. Ross ${ }^{3}$ describes the structure in S. montana, Klatt, as dorsiventral, with a convex lower surface and concave above. I have examined S. bicolor, Baker, and I find that the structure corresponds in general to Ross's brief description of $S$. montana. There is no strict symmetry about a midrib, and the main laterals $(m l$.) are larger than the median bundle ( $m . b$.$) , which$ does not occupy precisely the middle line of the leaf (Fig. 60). The only. Crocus to which such a leaf could be compared is C.carpetanus, and even
1 Cf. Petit, L. (1887).
2 Maw, G. (1886).
3 Ross, H. (1892-3). 
here the resembiance is not close. Syringodea seems rather to belong to the type of the bifacial species of Galaxia and Moraed.

Of the genus Galaxia, which is also confined to the Cape, I have examined two species. One of these, G. graminea, Thunb. (Figs. 65 A-E), shows that lack of synmetry which we have noticed as not unusual anong the Iridaceae. It has a sheath (Fig. $65 \mathrm{~A}$ ) passing into a solid limb (Fig, $65 \mathrm{C}$ ), which I interpret as a petiolar phyllode. The anatomy supports . this view; the structure, especially in the region near the apex (Figs. $65 \mathrm{D}$ and $\mathrm{E}$ ), recalls that of the type of ensiform leaf in which the bundles alternate. In another species, Galaxia ovata, Thunb. (Fig. 66), the only leaf which I have been able to examine was entirely dorsiventral, but it was probably an early leaf which had not achieved the mature form, since, according to Ross's ${ }^{1}$ description, the leaves of this species normally terminate in a short monofacial apex. It is evidently a species in which a typical petiolar phyllode, such as that found in Galaxia graminea, has been reduced until it consists chiefly of the leaf-base. The median bundle is unimportant as compared with the main laterals, and the general structure resembles that of various Moraeas. It may be recalled that the union of the stamens of Galaxia into a tube is also a character in which it approaches Moraea and differs from the other Crocoideae. It is quite possible that the genus ought to be removed into the Iridoideae, as has been suggested by Chodat and Balicka-Iwanowska. ${ }^{2}$

\section{Asymmetry in Certain IRID Leaves.}

A tendency to the reduction or loss of the median bundle, sometimes associated with a general lack of foliar symmetry about the adaxial-abaxial plane, is exhibited in many genera of Iridoideae and Crocoideae, though not, so far as I am aware, in the Ixioideae. In the Xiphium Section of the genus Iris, the midrib is, as a rule, insignificant in comparison with the laterals (e.g. Iris xiphioides, Figs. 31 C and D, p. 313). In the genus Moraea the midrib region is often thinner than the rest of the leaf, and traversed by several small bundles, of which sometimes no individual can be reckoned as actually median. This peculiarity is not confined to the leaf-sheath leaves (Figs. 36-8, p. 3 5 ), for there may be a complete absence of a median bundle in the dorsal region of an ensiform petiolar phyllode belonging to the genus (Figs. I2 A and B, p. 304). According to Ross's ${ }^{3}$ figures, there is also no median bundle in Bobartia and Ferraria. In the Crocoideae, Romulea (Figs. 6I-4, p: $3^{24}$ ), Crocus (Figs. $5^{6}$ and 57), and Syringodea (Fig. 60) are characterized by median bundles which are smaller than the main laterals, while in Galaxia (Figs. 65 and 66, p. 324) and Syringodea (Fig. 60) this reduction of the median bundle is associated with a lack

Ross, H. (1892-3).

2 Chodat, R., and Balicka-Iwanowski, G. (1892-3).

3 Ross, H. (1892-3). 
of general symmetry which makes it scarcely possible to identify a midrib. These conditions can be paralleled in the leaves of some of the Liliaceae, ${ }^{1}$ and in certain Dicotyledonous petioles and leaf-bases. For instance, a small median bundle and larger main laterals are found in certain species of Astelia, Allium, and Arnocrinum. (Liliaceae), and in the petiole of Antigonon (Polygonaceae), while the leaf-base phyllode of Anemarrhena (Liliaceae) and the leaf-sheath of Foeniculum (Umbelliferae) resemble the leaf of Crocus carpetantes in showing no obvious symmetry about a midrib. I do not know, however, of any cases in the Liliaceae exactly corresponding to that of the Moraeas in which there is no median bundle (e.g. M. Macleai, Figs. $12 \mathrm{~A}$ and B, p. $3^{\circ 4}$, and $M$. polystachya, Figs. $3^{6} \mathrm{~A}$ and B, p. $3^{\mathrm{I}} 5$ ), but the petioles of certain Labiates (Salvia Verbenaia, Fig. 39, p. 315, and Marrubium velutinum, ${ }^{2}$ Fig. $5^{8}$, p. $3^{24}$ ) show a corresponding lack of a median strand.

\section{The Evolutionary History of the irid Leaf.}

(i) The primitive character of the ensiform leaf-type.

In considering the evolution of the Irid leaf, the first necessity is to arrive at some working hypothesis as to what foliar type is to be regarded as primitive for the family. As I have shown on pp. 302 and 303 , the typical ensiform (isobilateral equitant) leaf is met with in more than 30 of the 57 genera, including members of both the principal tribes, Iridoideae and Ixioideae. Not only is this form of leaf characteristic of the majority of Irids, but many of the other leaf forms met with in the family-however superficially different-prove on examination (as indicated in the preceding sections of this paper) to be easily derivable from the ensiform type. Among the Liliiflorae, it is not only in the Iridaceae that the ensiform leaf occurs-it is found also in the other two great families, the Liliaceae and Amaryllidaceae. Its distribution, both within the Iridaceae and in the Liliiflorae in general, justifies us in treating it as, in all probability, representing the leaf-type of the original Irid stock. The idea is consistent with Baker's ${ }^{3}$ suggestion that Hewardia (of the Colchicaceae) forms 'an excellent cornnecting link between Liliaceae and Iridaceae'-for in this monotypic genus the leaves are ensiform.

Within the genus Iris itself, there seems good reason to consider the ensiform leaf-type as primitive. Such a conclusion certainly follows if we accept the deduction from Dr. Willis's 'Law of Age and Area's that, within a limited group, the more widely ranging types are likely to be the

1. Arber, A. (19203), pp. 449, $46 \mathrm{I}$, and Figs. 1 and 34 .

2 Petit, L. (1887); in the case of Salvia Verbenaca I have failed to find the small median bundle figured by Petit.

3 Baker, J. G. (1880).

- Willis, J. C. (1914). 
more primitive. There is no single species of Iris $^{1}$ covering the range of the genus, but the rhizomatous Section Apogon, with its ensiform leavesto which the widely ranging $I$. Pseudacorus, L., and $I$. foetidissima, L., belong-taken as a whole, covers the entire area of distribution of the genus, from the Pacific Coast of North America in the West, to China and Japan in the East. The members of this Section far outnumber those of the" other subdivisions of the genus, and their numerousness, as well as the non-bearded perianth segments, may be taken as indications of the antiquity of the type. Ensiform leaves are also typical of the other large rhizomatous Section, Pogoniris, as well as of several smaller Sections of the genus. The bulbous Sections, Tetragonae, Xiphium, and Juno, on the other hand, have a non-ensiform leaf. There seems to be some degree of probability that in the Iridaceae the rhizome may have preceded the bulb. Among the Liliaceae the two related tribes which show the most generalized characters -Melianthoideae and Asphodeloideae-are prevailingly rhizomatous; it appears likely that it is from some such Liliaceous stock that the Irids have arisen. That the bulbous Irises represent a specialized and relatively. late development is also indicated by the fact that, in comparison with the rhizomatous types, they are confined to relatively restricted areas. The Tetragonae, whose leaves may, as I have shown, be regarded as a variant upon the ensiform type, are centred about Asia Minor and the Caucasus; the Xiphiums, which show transitions towards leaf-base leaves (p. 312), belong to the Iberian and North-west African regions; the Juno Irises, whose leaves are reduced to leaf-bases pure and simple (p. $3^{\mathrm{I}} 4$ ), though they are found from the Mediterranean to North-west India, cannot compete in range with the ensiform Apogon Section.

The Irises are confined to the Northern Hemisphere. That they represent a very ancient stock which has had a long time to differentiate, is indicated by the fact that the genus has a wider area of distribution than any other within the family: another point which also suggests the great age of the Iris type is that, with the one exception of $I$. setosa, Pall., ${ }^{2}$ all the American species are endemic. In Africa, south of the Atlas Mountains, Irises are absent, and their place is taken by the closely related genus Moraea, one species of which extends into Australasia. In the Moraeas we find typically ensiform leaves resembling those of the majority of Irises, as well. as reduced leaves recalling those of the Xiphinm Section. These two genera-Iris and Moraea-together range over almost the whole world except South America. The place of the Iridaceae, in tropical and subtropical America, seems to be taken by the Maricineae, of which Marica-.

1 On the distribution of members of the genus Iris, see Dykes, W. R. (1913).

2 See Dykes, W. R. (1913), pp. 93, 94. This /ris, of which a variety of forms are known to come true from seed, occurs in Northern Asia and passes into America through Kamtchatka and Alaska. It is thus possible that it entered America in relatively recent times, though sufficiently long ago to have become differ entiated in that continent into a variety of distinct types. 
the largest and most widely spread genus-has an ensiform leaf. It is also significant that Marica is rhizomatous, whereas the other two genera, Trimezia and Cypella, are bulbous. The differences between Iris, Moraea, and Marica seem to be of quite subordinate importance, and I think we may reasonably regard these genera as the three modern representatives, differentiated in the Northern Hemisphere, Africa, and South America respectively, from one primaeval world-rangging Irid type, ${ }^{1}$ and still retaining many of its generalized characters, including the ensiform leaf.

\section{(ii) The progression from the ensiform leaf-type.}

Under the ensiform type we must include not only the typical equitant phyllodes, such as those illustrated in Figs. I-I3, p. 304, but also the forms, such as Sisyrinchizum junceum (Fig. 27, p. $3^{11}$ ), which only differ in the matter of proportion from the ensiform leaf of other members of the same genus-the width being greater relatively to the distance between the dorsal and ventral margins. How easy the passage from the truly ensiform to the cylindrical types can be, is seen in the genus Acacia, where there are ensiform phyllodes such as $A$. pendula (Fig. I4, p. 304) and A. uncinella (Fig. 42, p. 318 ), and, at the other end of the scale, cylindrical phyllodes such as that of $A$. teretifolia (Fig. 28, p. 3II). In the genus Iris we get a similar progression from the ensiform types, through the limb of I. Xiphium, with its oval section (Fig. $3^{2}$ B, p. 313 ), to the cylindrical limb of $I$. xiphioides (Fig. 3I D, p. 3I3).

From the ensiform leaf-using the term in the wide sense-the course of evolution shows signs of having proceeded in two directions, the petiolar. limb being either reduced in all degrees down to the point of actual elimination, or eise elaborated until it sometimes forms a highly complex pseudo-lamina.

The leaf-bases of equitant leaves in many cases show a marked capacity for development : for instance, in Micranthus alopecuroideus, Eckl., the leafsheaths may be extremely long. In certain genera the leaf-sheath is so far developed as to play the more conspicuous rôle, while the petiolar limb either remains as a well-marked organ or is reduced to a mere vestige. In a previous paper ${ }^{2}$ I have discussed the occurrence of such leaves in the Liliaceae; in the Iridaceae instances are found in the genera Iris (Xiphium Section) (p: 31 2), Moraea (pp. 314-15), Hoineria, Hexaglottis, and Galaxia.? In the literature, these cases are not referred to in the terms of the phyllode theory which I have here employed, but the leaves are merely described, non-committally, as bifacial with a monofacial apex.

In the Juno Irises reduction has gone still farther and the leaves are

1 For an exposition of the view that' all the great families of flowering plants have passed through a period when they existed in an undifferentiated world-ranging form, see Guppy, $\mathrm{H}$. B. (1919).

2 Arber, A. $\left(1920^{1}\right)$.

s Ross, H. (1892-3). 
exclusively of leaf-base nature. In this Section the bristle-like inner perianth segments'also suggest reduction-specialization. It should be recognized that the passage from the petiolar phyllode to the leaf-base leaf, though morphologically a reduction, may, from the standpoint of function, represent an advance. The leaf-bases of the Juno Irises, for instance, approach more nearly to true laminae, in structure and orientation, than do the petiolar phyllodes of the rest of the genus. The approximation to a normal Dicotyledonous blade, reached on this line of progression by the loss of the petiole and the exaggeration of the leaf-base, is arrived at on the second line of progression by a converse process-namely, elaboration of the petiole; by increase of surface relatively to sectional area, the limb is modified into a pseudo-lamina, which is a more powerful instrument for performing the work of the leaf. This elaboration seems to depend essentially upon invagination or grooving, which may or may not be associated with the production of keels or wings. Grooving of the leaftissue between the bundles is highly characteristic of the family; it occurs conspicuously in the leaf-base leaves of Crocus carpetanus (Fig. 59, p. 324) and Moraea bituminosa (Fig. 37, p. 315), as well as in various petiolar leaves. In the latter the invagination may be so slight as to result merely in a series of ribs and channels, such as those seen in Iris xiphioides (Figs. $3^{1 \mathrm{C}}$ and D, p. 313) and Romulea (Figs. 61-3, p. 324), or it may go much farther, and, as we have seen in the section on Foliated Leaves (pp. 320-3, and Figs. 50-3, p. 321), it may produce the curious pseudo-plicate winged leaves of Cypella, \&c. Even the anomalous leaves of Crocus are susceptible, as I have shown on p. 325 , of explanation on the same lines. The changes which take place in the petiolar phyllodes of the Irids, in their effort-if we may use the term-to become more effective assimilating organs, recall the peculiar stem developments which arise in the succulent Cactaceae and Euphorbias when the axis takes on the work normally accomplished by the leaf; in both cases we find corresponding morphological changes associated with the assumption, by a radial or approximately radial organ, of work which requires a large surface. The remarkable winged stem of Euphorbia grandicornis, which, as Goebel ${ }^{1}$ points out, exposes a surface scarcely inferior to that of a leafy shoot, may be broadly compared with the foliated petiolar phyllode of Cypella or Herbertia, which forms an organ in which the ratio of surface to volume must be greater than in many normal laminae.

The ingeniously diversified leaf-forms of the Iridaceae afford an illustration of the principle which I have termed the Law of Loss. ${ }^{2}$ On the phyllode theory, the leaf of the ancestral Irid, in common with other primaeval Monocotyledons, was of a type, in which the lamina had been entirely eliminated, and, on the Law of Loss, this lamina having been once 
discarded, could never be regained. A review of the Irid leaves leads us to the conclusion that there has been, as it were, an effort in this family to find some substitute for the lost lamina which would be more efficient than the typical petiolar phyllode as an organ of assimilation. The members of the family have all had the same problem to solve, and the same material-the petiolar phyllode-to work upon; they have apparently discovered no methods by which to deal with the situation, except invagination and the development of keels or wings. But we have only to compare the mature leaves of such divergent types as Gladiolus tristis (Fig. 48 J, p. $3^{18}$ ), Crocus (Fig. 56 I, p. 324), and Cypella (Fig. 50 N, p. 32 I), to see what strikingly different results have been attained by the various modes in which these monotonous methods have been applied.

In surveying the whole range of Irid leaf forms, one can scarcely fail to be struck by the more or less parallel developments from the ensiform type which have recurred within different tribes and genera. In the Iridoideae we meet, in the genus Iris, with ensiform and ' radial' phyllodes, and also with leaf-base leaves; with both ensiform and cylindrical phyllodes in each of the genera Sisyrinchium, Trimezia, and Bobartia; with foliated leaves in Cipura, Cypella, and Tigridia. In the Ixioideae there are many ensiform leaves, such as those of Schizostylis; ensiform leaves and also approximately radial phyllodes in Gladiolus; foliated leaves in Babiana. A corresponding series of 'Parallelbildungen.' has been recognized in the different genera of Cactaceae; Ganong ${ }^{1}$ enumerates a number of characters which recur repeatedly in different lines within the family. One is reminded also of the 'phyletic drift' recognized by Bower ${ }^{2}$ in the case of the ferns.

\section{Io. Summary.}

In the present paper a general examination of the leaf structure of the Iridaceae is undertaken, in order. to see how far the view can be substantiated that the leaf in this family is a phyllode, possessing no lamina but consisting of petiole and leaf-base, or leaf-base alone. It is found that a study of the transition region between sheath and limb often throws light on the morphology of the leaf.

The ensiform (equitant isobilateral) leaf is first discussed, and the conclusion is reached that the evidence-especially the comparison with modified leaves in the genus Acacia-negatives the congenital concrescence theory, and points to the ensiform leaf being a petiolar phyllode (pp. 303-6). The semi-equitant leaves of Phormium and Dianella (Liliaceae) are held not to be comparable with the ensiform leaves of the Iridaceae, but to have attained their curious form as a secondary modification (pp. 306-7). It is shown that not only are ensiform leaves in many respects similar to Acacia 
phyllodes, but even the minor detail of the association of ensiform leaves and winged axes, sometimes met with in the Iridaceae and other Monocotyledons, can be paralleled in the genus Acacia (pp. 308-10). The nature of the 'radial leaves' of Hermodaciylus, certain species of Iris, \&c., is discussed, and it is shown that these leaves are merely variants upon the ensiform type (pp. 310-12); and that they lead on to the leaves of certain Irises and Moraeas, which are mainly dorsiventral, but have a monofacial apex; such leaves are regarded as leaf-bases terminating in a more or less vestigial petiole (pp.312-16). The leaves of the Juno Irises are interpreted as being exclusively of leaf-base nature (p. $3^{14}$ ). The leaves of the Ixioideae are next considered, and the origin of the cruciform leaf of Gladiolis tristis is traced in detail. It is shown that all such leaves are again mere modifications of the ensiform type, and that the leaves of various species of Gladiolus can be paralleled within the genus Acacia (pp. 3I7-19). Attention is drawn to the resemblance which many Irids and Acacias bear to one another in their tendency to excessive foliar fibrosis, and the significance of this is considered (pp. $3^{1} 9^{-20}$ ). The peculiar foliated leaf-types met with in Babiana, Cypella, $\& c_{\text {: }}$, are examined, and it is shown that they arise from a simple petiolar structure, through invaginations, sometimes associated with the development of keels or wings (pp. 320-3). The leaves of the Crocoideae then come under consideration, and it is demonstrated that the gulf hitherto supposed to separate those of Crocus and Romulea has no real existence, but that the transition from sheath to limb shows that both leaves are petiolar phyllodes of an essentially similar type and that their divergent mature forms are merely the results of differing types of invagination (pp. $3^{2} 3^{-8}$ ). It is pointed out that the tendency to reduction or loss of the median bundle, which seems inherent in the leaves of the Iridaceae, can be paralleled in certain rare cases among Dicotyledonous petioles (pp. 328-9).

Finally, the evolutionary history of the Irid leaf is discussed, and it is concluded that the ensiform petiolar phyllode is probably primary for the family, and that the various leaf-types met with at the present day are to be interpreted either as reduced from the ensiform type by the more or less complete loss of the petiolar region, or else as elaborated from this petiolar region by invagination and winging (pp. 329-33).

Balfour Laboratory, Cambridge. 


\section{Alphabetical List of Memoirs cited.}

Arber, A. (1918): The Pbyllode Theory of the Monocotyledonous Leaf, with Special Reference to Anatomical Evidence. Ann. Bot., vol. xxxii, 1918, pp. 465-501, thirty-two text-figures.

(1919 $)$ : The Vegetative Morphology of Pistia and the Lemnaceae. Proc. Roy. Soc.,

B., vol. xci, 1919, pp. 96-103, eight text-figures.

(1919'): The 'Law of Loss' in Evolution. Proc. Linn. Soc., Lond., Session I31, $1918-19$, pp. 70-8.

$\left(1920^{2}\right)$ : Leaf-base Phyllodes among the Liliaceae. Bot. Gaz., vol. lxix, 1920, pp. 337-

40, four text-figures.

$\left(1920^{2}\right)$ : Tendrils of Smilax. Bot. Gaz., vol. lxix, 1920, pp. $43^{8-42}$, one plate.

$\left(1920^{3}\right)$ : On the Leaf Structure of certain Liliaceae, considered in Relation to the Phyllode

Theory. Ann. Bot, vol. xxxiv, 1920, pp. 447-65, thirty-eight text-figures.

Baker, J. G. (1878): Systema Iridacearum. Journ. Linn. Soc., vol. xvi, i878, pp. 61-18o.

(1880): A Synopsis of Colchicaceae and the Aberrant Tribes of Liliaceae. Linn. Journ. Bot., vol. xvii, I880, pp. 405-5ro.

(1892) : Handbook of the Irideae. London, $1892, x i i+247 \mathrm{pp}$.

Balicka-Iwanowska, G. (1892-3) : Contribution à l'étude anatomique et systématique du genre Iris et des genres voisins. Bibl. Universelle, Arch. des sci. phys. et nat. (Genève), Pér. III, t. xxviii, $189^{2}$, pp. $413-35$; t. xxix, 1893 , pp. $185-200,225^{-4}$, three plates, fifteen text-figures.

(See also Chodat, R., and Balicka.Iwanowska, G. (1892).

BÉguinot, A. (1907-9): Revisione monografica del genere Romulea, Maratti. Malpighia, vol. xxi, 1907 , pp. 49-122, fifteen text-figures, and pp. 364-478; vol. xxii, 1908, pp. 377-469; vol. xxiii, 1909, pp. 55-117, 185-239, 257-96.

Bower, F. O. (1918): Hooker Lecture : On the Natural Classification of Plants, as exemplified in the Filicales. Journ. Linn. Soc., Bot., vol. xliv, No. 296, 1918, pp. 107-24.

Candolle, A. P. DE (1827): Organographie végétale. Vol. i. Paris, $1827, x x+55^{8} \mathrm{pp}$.

ČlakovskÝ, L. J. (1903) : O listech monofaciálních. Rozpravy Ceské Akad. Císare Fr. Josefa, Třida ii, Roð. xii, 1903, Ćíslo 8, 40 pages, forty text-figures. (Abstracted Bot. Centralbl., vol. xciii, p. 343, 1903.)

Chodat, R., and Balicka-Iwanowska, G. (1892): La feuille des Iridées. Journ. de Bot., vol. vi, I 892, pp. 220-32, 253-67, one plate and thirteen text-figures.

Church, A. H. (1908): Types of Floral Mechanism. Part I, Types i-xii. Oxford, I908.

(1919): Thalassiophyta and the Subaerial Transmigration. Bot. Memoirs, No. 3, Oxford, 1919, $95 \mathrm{pp}$.

Dykes, W. R. (1913): The Genus Iris. Cambridge, I913, 245 pp., forty-eight plates, and thirty text-figures.

Foster, M. (1892): Bulbous Irises. Royal Horticultural Society, 1892, 86 pp., fifty-eight text-figares.

Ganong, W. F. (1894): Beiträge zur Kenntniss der Morphologie und Biologie der Cacteen. Flora, Bd. lxxix (Ergänz. zum Jabrg. 1894), 1894, pp. 49-86, seventeen text-figures.

Goebel, K. (1889) : Pflanzenbiologische Schilderungen. Teil I. Marburg, 1889, iv +239 pp., ninety-eight text-figures, and nine plates.

(1905): Organography of Plants. Part II. Oxford, 1905, xxiv + 707 pp:, 417 textfigures.

- (1913): Organographie der Pflanzen. Teil 1, Aufl. 2. $x+5^{13}$ pp., 459 text-figures. Jena, 1913.

GraY, ASA (1887): Structural Botany, sixth edition. London, 1887 , xii $+44^{2}$ pp., 695 text-figures.

Guppy, H. B. (1919) : Plant-distribution from the Standpoint of an Idealist. Journ. Linn. Soc., Bot., vol. xliv, 1919, pp. 439-72.

Hooker, J. D. (1880): Xiphion Kolpakozskianum. Hooker's Bot. Mag., Tab. $6_{4} 89$, vol. xxxvi. Ser. III, 1880 .

IRMISCH, T. (1850): Zur Morphologie der monokotylischen Knollen- und Zwiebelgewächse. Berlin, I $850, x x i i+286$ pp., ten plates. 
Lin dMan, C. A. M. (1899): Zur Morphologie und Biologie einiger Blätter und belaubter Sprosse. Bihang till k. Svenska Vet.-Akad. Handl., Bd. xxv, Afd. iii, No. 4, 63 pp., twenty textfigures.

MAw, G. (1886): A Monograph of the Genus Crocus. London, 1886, viii $+326+x x$ pp., one maps 70 plates.

Pax, F. (1888): Iridaceae, in Engler, A., and Prantl, K., Die natürlichen Pflanzenfamilien, ii, 5, I888, pp. 137-57, thirty-five text-figures.

Petit, L. (1887) : Le pétiole des dicotylédones. Mém. de la Soc. des sci. phys. et nat. de Bordeaux, $3^{\circ}$ sér., t. iii, $1887, \mathrm{pp} .2$ I $7-404$, seven plates.

Ross, H. (1892-3) : Anatomia comparata delle foglie delle Iridee. Malpighia, Anno VI, I892, pp. 90-116, 179-205, four plates; Anno VII, 1893, pp. 345-9o.

Velẹnovský, J. (1907): Vergleichende Morphologie der Pflazzen. Teil II. Prag, 1907, 73 I pp., five plates, 455 text-figures.

Wil.is, J. C. (1914): The Endemic Flora of Ceylon, with Reference to Geographical Distribution and Evolution in general. Phil. Trans. Roy. Soc., London, Ser. B, vol. cevi, I914, pp. $307-42$, four text-figures. 